\title{
REVIEW
}

\section{Retrospective of the 1988 European seal epizootic}

\author{
M.-P. Heide-Jørgensen ${ }^{1}{ }$ T. Härkönen ${ }^{2}$, R. Dietz ${ }^{3}$, P. M. Thompson ${ }^{4}$ \\ ${ }^{1}$ Marine Mammal Section, Greenland Fisheries Research Institute, Tagensvej 135, DK-2200 Copenhagen N, Denmark \\ ${ }^{2}$ Tjärnö Marine Biological Laboratory, Pl 2781, S-452 00 Strömstad, Sweden \\ ${ }^{3}$ Greenland Environmental Research Institute, Tagensvej 135, DK-2200 Copenhagen N, Denmark \\ ${ }^{4}$ University of Aberdeen, Department of Zoology, Lighthouse Field Station, Cromarty IV11 8YJ, United Kingdom
}

\begin{abstract}
The disease that killed more than 18000 harbour seals Phoca vitulina and a small number of grey seals Halichoerus grypus in the North Sea, the Kattegat-Skagerrak and the southern Baltic in 1988 has now been well described for all afflicted areas, and the pathological and virological findings are in good concordance from all seal groups studied. The descriptions vary in detail but render little doubt that the disease had identical characteristics, and that a newly recognised virus, phocine distemper virus (PDV), of the genus Morbillivirus, was the primary cause of the disease. A number of viral and bacterial agents as well as parasites were identified in the dead seals, but none of them seem to be of primary importance for the development of the disease syndrome. The high mortality can probably be explained by the fact that a highly pathogenic virus was introduced into a naive population with no specific immunity to the infectious agent. It is also possible that factors such as organochlorine pollution or crowding of seals at haul-out sites may have exacerbated the impact of the disease in some areas. However, there are currently insufficient data to determine the potential role of these other factors in the severity of the outbreak. Antibodies to infections by canine distemper virus (CDV)-like viruses are present in both North Atlantic and Antarctic pinnipeds, but the immunological response is usually distinct from that to PDV. The pathogenicity of these infections is unknown, but likely less than for the virus that infected North Sea harbour seals in 1988. However, harp seals Phoca groenlandica are frequently infected by PDV and they have recently invaded the North Sea where they have been observed in the vicinity of harbour seal haul-out sites. Hence, migrating harp seals are a plausible vector of the virus. PDV has been transmitted to terrestrial carnivores causing distemper outbreaks in Danish farmed mink Mustela vison in 1989, and an epizootiological link cannot be excluded. There are no epizootiological links between the seal epizootic in North Western Europe in 1988-89 and the disease outbreaks in Baikal seals Phoca sibirica and high Arctic sled dogs in 1987-88.
\end{abstract}

\section{INTRODUCTION}

When massive numbers of dead harbour seals Phoca vitulina were washed ashore in northern Europe during the spring and summer of 1988 , it created a public sensation and a scientific dilemma. A large variety of studies on seal diseases, their effects and triggering mechanisms were initiated in response to the public outcry for better understanding of human impacts on marine ecosystems. This event was the first documented large-scale die-off of pinnipeds in Europe in modern times. It occurred during a period of increasing public concern about pollution and its impacts upon marine mammal populations, and during sum- mer months when many tourists could witness seal carcasses drifting at sea or washed ashore on beaches. However, it was certainly not the first mass die-off of marine mammals. Whales are known to die in large numbers in ice entrapments, by strandings, and possibly from poisoning by algae (Mitchell \& Reeves 1981, Martin et al. 1987, Perrin 1988, Geraci 1989a, b, Geraci et al. 1989). Dietz et al. (1989b) and Harwood \& Hall (1990) reviewed mass die-offs of seals. The most recent and well documented are those of crabeater seals Lobodon carcinophagus in the Antarctic in 1955 and of harbour seals in New England, USA, during 1979-80 (Laws \& Taylor 1957, Geraci et al. 1982). In the first of these, more than 3000 crabeater seals died and post- 
mortem findings were similar to those in Europe in 1988, but no serological examinations were made (Laws \& Taylor 1957). In New England, at least 500 harbour seals died in 1979-80, and an influenza virus probably of avian origin was identified as the primary cause of death. In fact, most reports of mass die-offs of marine mammals involve harbour seals. Harwood \& Hall (1990) mention several incidents from the 18th, 19 th and early 20 th centuries when large numbers of harbour seal carcasses were washed ashore around the British Isles. This is partly due to the coastal habits of harbour seals which makes recordings of carcasses more likely than for most other marine mammals.

This paper reviews pathology, epizootiology, mortality and population effects of the 1988 seal disease The primary cause has been established to be the morbillivirus, phocine distemper virus (PDV).

\section{EPIZOOTIOLOGY OF THE DISEASE}

\section{Dispersal}

The detailed mapping of the geographical dispersal of the disease during 1988 provided by Dietz et al (1989b) was generally confirmed at meetings of experts in the International Council for the Exploration of the Sea (ICES 1989, 1990). The disease erupted in the central Kattegat and was first detected by observations of unusual numbers of abortions on Anholt (Fig. 1). By early May, the disease had spread to the eastern Kattegat and into the Danish and Dutch Wadden Sea. In June, deaths were also noted in the Skagerrak and the German Wadden Sea and by July in the Oslo Fjord and the southern Baltic. The disease finally reached United Kingdom waters in August and deaths continued to be recorded in these areas until November (Hall et al. 1992a).

Dispersal rate of the disease was measured in the Kattegat-Skagerrak by comparing the time when peak numbers of dead seals were registered (i.e. when $50 \%$ of the total mortality at each locality was experienced) at the 12 main localities. It was found that the dispersal rate was inversely proportional to the distance between afflicted seal herds ( $p<0.05)$, but no correlation was found between herd size and dispersal rate (Heide-Jørgensen \& Härkönen 1992). In most other areas, fine-scale information on dispersal rates could not be collected because harbour seals do not haul out

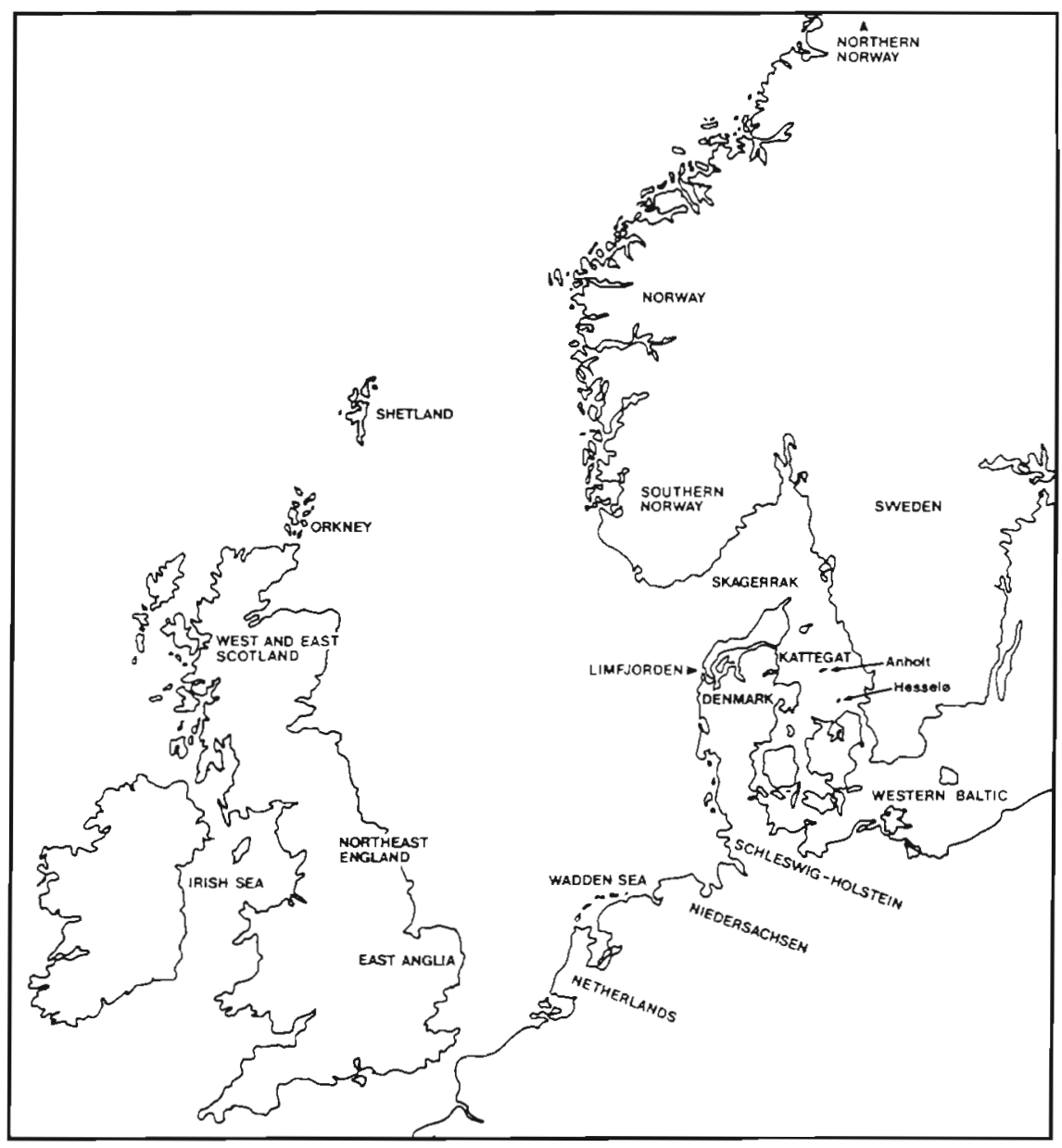

Fig. 1 Localities and areas mentioned in the text and in Table 1 
in discrete herds to the same degree as in the KattegatSkagerrak.

\section{Gross mortality and intensity of epizootic}

Total mortality. Dead harbour seals were recorded by local authorities, coast guards, members of the public and by biologists or veterinarians collecting data about the disease (Dietz et al. 1989b, HeideJørgensen \& Härkönen 1992, Hall et al. 1992a, Munro et al. 1992). The total number of dead seals recorded in European waters in 1988 exceeded 18000, of which $99 \%$ were harbour seals and $1 \%$ were grey seals Halichoerus grypus (Table 1, Dietz et al. 1989b, ICES 1990). This figure is substantially higher than in any other year; the total number for 1989 was less than 500 seals (Table 1). The cause of death was not determined for all seals in 1988 but it is likely that the majority of them died from the disease. However, in areas where relatively low mortality occurred, a smaller proportion of recorded deaths may have resulted from PDV. In northeast Scotland, for example, only $42 \%$ of 59 seals necropsied were shown to have died from morbillivirus infection (Munro et al. 1992). In 1989 only seals from northern Norway and the Wadden Sea showed symptoms resembling those of the disease in 1988 (Table 1).
Regional differences in mortality. Mortality in the different areas has been estimated for harbour seals by 2 methods: (1) comparison of stock sizes before and after the epizootic, and (2) comparison of expected stock sizes for 1988 with results of the surveys conducted after the epizootic. The first method gives a lower variance in the estimate of mortality, but may be biased if a population was increasing or decreasing prior to the epizootic. Using this method, mortality was estimated to be in the region of 40 to $50 \%$ in the Irish Sea and East Anglia (Harwood et al. 1991, ICES 1990) and 10 to $20 \%$ on the east coast of Scotland (Thompson \& Miller 1992). Use of the second method produced estimates of 40 to $60 \%$ mortality in the Kattegat-Skagerrak and Wadden Sea (Tougaard 1989. Härkönen \& Heide-Jørgensen 1990b, ICES 1990). Despite potential biases in the exact figure for mortality, it is clear that the impact of the disease was comparatively low in most parts of Scotland (ICES 1990). An estimate of the mortality in a seal group in the Oslo Fjord of $75 \%$ is based on comparison between the number of seals hauled out before the epizootic in 1988 and in 1989 (Markussen in press). However, this estimate includes pups born in 1989 and the same study presents evidence of movements of seals to other seal herds not included in the study. Using a deterministic compartment model of the disease outbreak in the United Kingdom, Grenfell et al. (1992) suggest that

Table 1. Number of dead harbour and grey seals recorded by area. Data from Dietz et al. (1989b) and ICES (1990). • Seals from 1989 showing symptoms of infection with phocine distemper virus

\begin{tabular}{|c|c|c|c|c|c|c|}
\hline Area & $\begin{array}{c}\text { Harbour } \\
\text { seals } \\
1988\end{array}$ & $\begin{array}{l}\text { Grey } \\
\text { seals } \\
1988\end{array}$ & $\begin{array}{c}\text { Uniden- } \\
\text { tified } \\
1988\end{array}$ & $\begin{array}{c}\text { Harbour } \\
\text { seals } \\
1989\end{array}$ & $\begin{array}{l}\text { Grey } \\
\text { seals } \\
1989\end{array}$ & $\begin{array}{c}\text { Uniden- } \\
\text { tified } \\
1989\end{array}$ \\
\hline Western Baltic & 151 & 5 & & 4 & 3 & \\
\hline Kattegat & 3909 & 3 & & $<20$ & & \\
\hline Skagerrak & 1469 & & & 18 & 1 & \\
\hline Limfjorden & 391 & & & 1 & & \\
\hline \multicolumn{7}{|l|}{ Wadden Sea } \\
\hline Denmark & 1238 & & & 22 & & \\
\hline Schleswig-Holstein & 5808 & 2 & & 91 & & \\
\hline Niedersachsen & 1100 & 4 & & $64^{\circ}$ & & \\
\hline Netherlands & 417 & & & $38^{\circ}$ & 2 & \\
\hline \multicolumn{7}{|l|}{ Norway } \\
\hline Southern Norway & 950 & & & & & \\
\hline Northern Norway & & & & $<50^{\circ}$ & & \\
\hline \multicolumn{7}{|l|}{ British Isles } \\
\hline \multicolumn{7}{|l|}{ East Anglia and Northeast } \\
\hline England & 316 & 57 & 1115 & 13 & 3 & 27 \\
\hline Irish Sea & 71 & 28 & 284 & 0 & 1 & 4 \\
\hline Orkney & 159 & 4 & 369 & 66 & & 3 \\
\hline West and North Scotland & 185 & 40 & 349 & 14 & 5 & 5 \\
\hline Shetland & 34 & 8 & 17 & & & 2 \\
\hline East Scotland & 59 & 23 & 52 & 4 & 7 & 4 \\
\hline Total & 16257 & 174 & 2186 & $<405$ & 26 & 45 \\
\hline
\end{tabular}


observed differences in mortality can be explained by assuming either that the proportion of infected animals which died ranged from 0.15 to 0.67 , or that the number of sufficient contacts varied by a factor of 3 . The high prevalence of antibodies in survivors from areas of low mortality (Harwood et al. 1989. Thompson et al. 1992) indicate that most infected seals survived. However, it has also been suggested that, in lowdensity herds, low doses of virus could produce a humoral response without causing infection (Kennedy 1990). The cause behind the observed differences in mortality therefore remains unclear.

Although serological studies indicate that a high proportion of United Kingdom grey seals encountered PDV during 1988 (Harwood et al. 1989, Cornwell et al. 1992), annual surveys at their breeding colonies suggest that the disease caused little additional mortality in this species (Harwood et al. 1991). However, pup production at several major colonies was 6 to $24 \%$ lower than expected in 1988 (Harwood et al. 1991) and it is possible that this could have resulted from PDV infection.

Mortality as index of epizootic intensity. In the central Kattegat the disease erupted in April and May, a time when females are carrying near-term foetuses. Nearly all females at the 2 first affected localities either aborted or lost their pups due to the disease or abandonment (Heide-Jørgensen \& Härkönen 1992). This shows that nearly all (>95\%) of the pregnant females present at these 2 localities were infected. Males had a higher mortality (see section 'Sex- and age-related mortalities'), so a similar or higher proportion of males is expected to have been infected. Thus, an intensity of more than $95 \%$ in seals of both sexes present close to the haul-out sites can be inferred (Heide-Jørgensen \& Härkönen 1992).

Blood serum sampled in Britain in 1989 showed that $88 \%$ of seals older than 2 yr $(n=32)$ were seropositive, whereas only $12 \%$ of younger seals ( $n=24)$ had antibodies against morbilli virus (Harwood et al. 1989, see section 'Disease agents'). The implication is that, if mortality in Britain was $60 \%$, then the intensity of the epizootic must have been about $95 \%$ in British waters in the population older than 1 yr. Scottish harbour seals had a similarly high prevalence of antibodies, suggesting that the low mortality observed there was due either to higher resistance in the seals or to mutation of the virus (Thompson et al. 1992). This may also be a consequence of dose-effect related differences in humoral response as suggested by Kennedy (1990).

\section{Sex-and age-related mortalities}

Detailed information on age-specific mortality is available from the Kattegat-Skagerrak (Härkonen \&
Heide-Jørgensen 1990a), the Danish (Danish Environmental Research Institute, Kalø, Denmark) and north German parts of the Wadden Sea (Marsh \& Scheibel 1989), and the United Kingdom (Hall et al. 1992) Approximate tentative age estimations were made for broad age classes in the Limfjord (Danish Environmental Research Institute, Kalo, Denmark, unpubl. data) and the Niedersachsen coast of Germany (Stede 1990a). In the latter cases, the imprecise ageestimation technique precludes the use of the results in detailed analyses. Techniques for proper age determination are given in Dietz et al. (1991).

Sex ratio of dead pups was not significantly different from $1: 1$ in areas where the disease peaked during pupping, suckling or weaning. In these areas, where pups died from abortions, abandonment or infections, a pup mortality close to $100 \%$ was experienced (Dietz et al. 1989b, Heide-Jørgensen \& Härkönen 1992). Later in the season pups in good condition died from the infection, and these areas showed a larger proportion of dead male pups (Heide-Jørgensen \& Härkönen 1992, Danish Environmental Research Institute, Kalø, Denmark, unpubl, data).

The disease did not arrive in the United Kingdom until August, well after the end of lactation. There, pups born in 1988 were under-represented in the sample of dead seals and the sex-ratio of dead pups was close to $1: 1$ (Hall et al. 1992a). The low number of dead pups, and the similarly low prevalence of morbillivirus antibodies in this age-class (Harwood et al. 1989) suggest that the tendency for weaned pups to haul-out less frequently (Thompson \& Harwood 1990) may have reduced their contact with infected individuals.

In seals older than pups (>6 mo), males were the first to be affected, and they died in significantly higher proportions during the first half of the epizootic period at most localities, whereas females dominated in the second half (Heide-Jørgensen \& Härkönen 1992). The total proportion of dead seals that were males varied between localities, probably as a result of the time when the disease was introduced. At localities exposed early in the season, 45 to $60 \%$ were males, compared with 55 to $75 \%$ at localities affected during peak moult or later (Marsh \& Scheibel 1989, Heide-Jørgensen \& Härkönen 1992, Hall et al. 1992a, Danish Environmental Research Institute, Kalø, Denmark, unpubl. data).

Age structure of dead seals of more than 1 yr of age differed significantly between stocks. More than $70 \%$ of the dead seals of more than 1 yr were adults (exceeding $4 \mathrm{yr}$ of age) in areas where the epizootic raged early in the season (Härkönen \& HeideJørgensen 1990 b), compared with about $50 \%$ in areas affected during moult or later (Marsh \& Scheibel 1989, 
Hall et al. 1992a, Danish Environmental Research Institute, Kalø, Denmark, unpubl. data).

These geographical and temporal variations in the structure of the samples of dead seals could have resulted either from behaviour-mediated differences in contact rate, or from variations in the immune status of different age or sex classes. The higher proportion of dead males in areas where the disease arrived late in the summer may have been due to males spending more time ashore at this time of the year (Thompson et al. 1989). Alternatively, certain classes of seals may have been more vulnerable to disease at particular stages of the annual cycle, e.g. when females are in poor body condition towards the end of lactation. Whatever the cause of these differences, it is clear that age-specific mortality profiles were not constant throughout the region. Consequently, the long-term effects of the mortality must be evaluated separately for different seal stocks.

\section{Threshold size of seal herds}

Epizootiological modelling has been carried out for the Kattegat-Skagerrak, where the dynamics of the epizootic were studied in detail at 5 localities. A large proportion of the dead seals were recorded at these sites, from herds ranging in size before the epizootic from 80 to 1500 individuals (Heide-Jørgensen \& Härkönen 1992). A discrete stochastic model showed that, within such a range, no fixed threshold size of a seal herd was required for an epizootic to expand and that widely separated seal herds showed similar dynamics of the epizootic. These findings probably can be explained by the gregarious behaviour of harbour seals: nearly all seals present at each locality eventually became infected, regardless of the absolute size of the seal herd.

\section{Recurrent cycles}

It has been suggested that mass mortalities in marine mammals could play an important role in determining long-term average population sizes (Harwood \& Hall 1990). The disease afflicting the seals in 1988 was probably new to most of the North Sea harbour seals, although the low number of samples available from before the epizootic means that evidence of previous outbreaks would have been missed. Emerging diseases are more devastating when they are new to a population (Miller 1989). Other incidents of epizootics resulted in low mortality (5\% or less) in affected groups and/or involved only small isolated groups within the wide geographical range of the species.
Few recurrent outbreaks of disease documented for pinnipeds have shown rapidly dampened oscillations. For example, the influenza epizootic in New England in 1979-1980 was followed by an outbreak in 1982, but the mortality resulting from the second outbreak was considerably lower (Geraci et al. 1984). Recycling of canine distemper virus (CDV) in crabeater seals is indicated by the fact that a majority of mature individuals in 1989 had antibodies to CDV, and a smaller proportion of the youngest year classes ( 0 to $4 \mathrm{yr}$ ) showed evidence of contact with the infective agent (Bengtson et al. 1991).

The model of Grenfell et al. (1992) for a single PDV epizootic indicates that the transmission potential for the virus was so high that the infection could not persist in a single North Sea colony beyond 1988. Analysis of longer-term trends suggested that, if PDV was reintroduced, it would not cause a major epizootic until the proportion of susceptible seals had built up for at least 10 yr. However, the model assumed that there were no spatial, seasonal, age- or sex-specific variations in transmission rate, which this review has shown is unlikely to be the case. More importantly, the model did not account for the fact that the North Sea harbour seal population is spatially structured, and that herds were successively infected. Consequently, we suggest that the predictions from this preliminary and rather crude model should be treated with caution.

Several lines of evidence suggest that specific immunity persists once seals have been exposed to morbilliviruses. In dogs, CDV antibodies persist for a lifetime (Appel 1987). Furthermore, maternal antibodies were present in samples from pups caught in the United Kingdom (Cornwell et al. 1992) and in Norway (Markussen in press) during 1990, 2 yr after the epizootic. In the United Kingdom, however, a large proportion of the younger seals escaped the infection and appeared as susceptibles in seroconversion tests 1 and 2 yr after the epizootic (Harwood et al. 1989, Carter et al. 1990, Cornwell et al. 1992).

\section{Probability of extinction due to repeated epizootics}

Harwood \& Hall (1990) reviewed mathematical models of epizootics and the role of epizootics in population dynamics. They found that the models were applicable primarily to short-lived species with rapid turnover rates. Harbour seals, like other pinnipeds, are long-lived animals that aggregate seasonally to breed or moult. Viral diseases in such species would resemble epidemics of venereal disease in humans. Population density has little or no effect on the development of the epidemic because infectives always come into contact with susceptibles even when the numbers of individuals are low. 
The social organization and behaviour of pinnipeds make them vulnerable to repeated epizootics. On an evolutionary time scale, the probability of extinction should be high. However, evident persistence of pinnipeds shows that aspects of their behaviour or ecology have provided a strategy for survival. Can the North Sea seal epizootic give some clues to this strategy? One way to address this question might be to investigate populations or parts of populations that escaped the disease.

During the 1988 epizootic, deaths were not recorded in harbour seal populations in Iceland, Svalbard, northern Norway or the northern Baltic. Nevertheless, it is possible that low mortality in these remote populations could have been missed, and no blood samples have been obtained to confirm whether or not these populations came into contact with PDV in 1988. Relative geographical isolation may, however, have resulted in these populations not being infected. Distances to and sizes of neighbouring seal herds and relative geographical isolation may explain why these seal herds escaped the disease. Dispersal rate of the disease between seal herds is correlated to distance between herds in the Kattegat-Skagerrak (HeideJørgensen \& Härkönen 1992). Theoretically, then, it is reasonable to infer that long distances sometimes act as barriers against dispersal. In diseases with short infectious periods, peripherial sub-populations can escape epizootics and thereby provide a pool of survivors that can contribute to the recovery of the population. Also, some seal herds or sex and ageclasses within herds may survive if the disease rages outside the peak periods of aggregation on land.

In continental Europe, total mortality was roughly $60 \%$ (Härkönen \& Heide-Jørgensen 1990b, ICES 1990), but in some areas adults died in substantially higher frequencies than subadults (Härkonen \& Heide-Jørgensen 1990a). This finding suggests that more subadults than adults were absent from the haulout site during the infectious period. It is supported by serological results from Britain, where fewer young individuals than adults were seropositive after the epizootic (Harwood et al. 1989).

Thus, behavioural and ecological features of pinniped populations provide possible explanations for how gregarious long-lived animals avoid extinction during severe epizootics

\section{DISEASE MANIFESTATIONS}

Clinical symptoms, macroscopic observations and histology have been described for harbour seals from Denmark, Germany, Norway, United Kingdom (Northern Ireland, Scotland) and Sweden. Generally, the pathology of the diseased seals was similar to that caused by canine distemper infection in dogs (see Appel 1987). Grey seals seemed to be less susceptible to the disease than harbour seals. This is clear from the low grey seal mortality around United Kingdom where they are more common than harbour seals (Harwood et al. 1991). The lower susceptibility was also confirmed in experimental inoculations of the pathogenic virus in a captive grey seal (Harder et al. 1990).

\section{Clinical symptoms}

Several investigators report that diseased seals showed sluggishness on land, inability to escape, disinclination to return to the sea, inability to dive, apathy, coughing, dyspnoea and nasal discharge (Breuer et al. 1988d, Kennedy et al. 1989b, Bergman et al. 1990, Krogsrud et al. 1990, Stede 1990a, Munro et al. 1992). Some seals showed neurological disturbances such as muscle tremor and uncoordinated movements, and in some individuals haemorrhagic diathese and fever as high as $41^{\circ} \mathrm{C}$ was observed (Breuer et al. 1988d). Many seals had subcutaneous swellings in upper parts of the cervical and thoracic regions (Kennedy et al. 1989b, Bergman et al. 1990). Some had catarrhal symptoms such as rhinitis, conjunctivitis and diarrhoea (Kennedy et al. 1989b, Bergman et al. 1990, Heje et al. 1992). Diseased females often aborted their near and full term pups, which then died from starvation or premature birth (Härkönen \& Heide-Jørgensen 1990b).

\section{Macroscopical and histological findings}

Generally, the seals were in good nutritive condition, with blubber layers more than $1.5 \mathrm{~cm}$ thick during June (Breuer et al. 1988c, Breuer et al. 1988d, Härkönen \& Heide-Jørgensen 1990a, Baker 1992). Lesions in respiratory and lymphatic organs were characteristic for most of the dead seals (Kennedy et al. 1989b, Bergman et al. 1990, Baker 1992, Munro et al. 1992). Also liver and intestinal lesions were frequently found (Stede 1990a).

Respiratory organs. Macroscopical signs of pneumonia, with secondary severe emphysema of pulmonary alveoli, interstitium, mediastinum and subcutaneous tissues of dorsal parts of the neck and thoracic regions, were found consistently in the seals (Breuer et al. 1988c, Kennedy et al. 1988a, 1989b Bergman et al. 1990, Stede 1990a, Heje et al. 1992, Munro et al. 1992), particularly in cases where pneumonia was considered the immediate cause of death (Breuer et al. 1988c, Heje et al. 1992) 
Some seals had collapsed lungs with congestion and haemorrhagic lung infarct, mucopurulent exudates in the bronchi, interlobular oedema and emphysema, and hyaline membranes with oedema (Breuer et al. 1988d, Kennedy et al. 1989b, Krogsrud et al. 1990, Schumacher et al. 1990, Baker 1992). The bronchial exudate was usually reddish-brown and mucoid (Munro et al. 1992)

In microscopical examinations the predominant lesion in the lungs was an interstitial pneumonia showing widened interalveolar septa due to oedema and accumulation of mononuclear cells of histiocytic type and broncho-alveolar and interstitial pneumonia with alveolar infiltration of granulocytes (Kennedy et al. 1989b, Bergman et al. 1990, Krogsrud et al. 1990, Munro et al. 1992). Also, congestion of alveolar capillaries, alveolar oedema, and proliferation of alveolar epithelial cells and inclusion bodies in alveolar macrophages were found (Kennedy et al. 1989b, Krogsrud et al. 1990, Heje et al. 1992). Intracytoplasmic inclusion bodies were often found in the epithelial cells of trachea (Bergman et al. 1990, Krogsrud et al. 1990, Heje et al. 1992, Munro et al. 1992)

In German seals infestations by lung parasites (see sections on parasites) were described and histologic examination of lungs was not possible because of a perifocal, non-purulent interstitial cell infiltration caused by the parasites (Breuer et al. 1988a, Hofmeister et al. 1988, Schumacher et al. 1990).

Lymphatic organs. Macroscopically the lymphatic organs appeared small and atrophic with occasional enlargements of the bronchial lymph nodes and/or the spleen due to secondary bacterial infection (Bergman et al. 1990). According to Breuer et al. (1988d), Kennedy et al. (1989b), Krogsrud et al. (1990) and Munro et al. (1992) lymph nodes were enlarged and oedematous. Microscopically, lymphatic tissues including the gutassociated lymphoid follicles were characterized by severe depletion of lymphocytes (Bergman et al. 1990, Pohlmeyer 1990, Schumacher et al. 1990, Munro et al. 1992, Baker 1992). Cortical lymphocytes in the thymus were depleted and therefore the cortex appeared narrow and thin (Bergman et al. 1990). In lymph nodes depletion of lymphocytes led to atrophy of cortical and paracortical regions (Bergman et al. 1990, Schumacher et al. 1990, Heje et al. 1992). Focal areas of necrosis were seen in lymph nodes of lungs (Krogsrud et al. 1990).

The thymus was examined in a few of the seals found dead in the United Kingdom, and these too showed sign of involution and a lack of thymocytes (Baker 1992, Kendall et al. 1992). Blood thymulin levels in live grey seals were inversely related to CDV titres, indicating that PDV was having an immuno-suppressive effect even on those individuals which survived infection (Kendall et al. 1992).

In the spleen, the dominant lesions were located to the white pulp with lymphocyte depletion both of the periarteriolar lymphocyte sheaths and the lymphoid follicles (Bergman et al. 1990). Other observations were slight atrophy of the white pulp with lymphocyte depletion, presence of pigment-loaded macrophages and acute congestion, and necrosis (Kennedy et al. 1989b, Schumacher et al. 1990). Gut-associated lymphatic tissue showed lymphocyte depletion of the follicles in the Peyer's patches (Bergman et al. 1990). Macroscopically the spleen showed hypertrophy and a tar-like composition of the sectional plane (Stede 1990a).

Brain. The brain changes were characteristic of nonsuppurative encephalitis (Kennedy et al. 1989b, Munro et al. 1992). Brain lesions were described in detail by Kennedy et al. (1989b) and they included severe demyelination in subependymal and subpial white matter, where proliferation of astrocytes and formation of gemastocytes and syncytia were also noted. Neuronal necrosis, gliosis and perivascular cuffing were also common in the cerebral cortex.

Brains of 31 seals from Germany were examined histologically, and in 19 of these the neuropathological alterations included multifocal, non-purulent, perivenous cuffs in different degrees, particularly in the white matter of the cerebellum and the brain stem, and, of these, especially the cerebellar folia and peduncles. In 14 individuals, non-purulent ependymitis and ependymal oedema was found in addition, and in 8 individuals, multifocal demyelinating leukoencephalitis also was found (Breuer et al. 1988a, Hofmeister et al. 1988). Intracytoplasmic and intranuclear eosinophil inclusion bodies were present in neurons in 6 German seals and were common in Irish seals (Hofmeister et al. 1988, Kennedy et al. 1989b). All these brain lesions are similar to CDV-provoked encephalitis in dogs (Breuer et al. 1988a, Hofmeister et al. 1988).

Miscellaneous lesions. Some urinary bladders had intracytoplasmic eosinophilic inclusion bodies (Kennedy et al. 1989b, Bergman et al. 1990, Munro et al. 1992). Catarrhalic and haemorrhagic inflammation of the stomach and intestine accompained by severe hepatic lesions were among the main symptoms of the disease (Stede 1990a, 1990b). Acute congestion of 10 livers ( $n=21)$ and 3 kidneys $(n=18)$ was observed in seals from Germany. Severe congestion of livers and spleen was seen in most Danish and Scottish seals (Heje et al. 1992, Munro et al. 1992). Atrophy of adrenal glands was seen in 2 seals (Schumacher et al. 1990) but hypertrophy was found in most cases (Stede 1989). Intracytoplasmic and intranuclear inclusions were also seen in gastric epithelial cells (Kennedy et al. 1989b). 


\section{DISEASE AGENTS}

\section{Herpesviruses}

Initially, a herpesvirus was isolated and thought to be of importance for the disease syndrome of the seals (Osterhaus 1988, Osterhaus et al. 1990). However, herpesvirus was isolated in only 23 of 114 tested seals from Denmark (Have et al. 1992). A German screening of 71 free-ranging and 41 captive seals revealed presence of infectious herpesviruses in 1 and 3 seals, respectively (Frey et al. 1989). Six virus isolates were considered herpes-like on the basis of cytopathic changes. Neutralization tests using the virus isolates showed that $53 \%$ of the free-ranging seals were seropositive to one of the isolates, whereas less than $22 \%$ of the captive seals were seropositive (Frey et al. 1989). Earlier, a herpesvirus was isolated from an outbreak of an epizootic amongst captive seals in Holland, where 11 of 23 pups died (Osterhaus et al. 1985). A related herpesvirus was found to be widespread in free-ranging pinnipeds (Osterhaus et al. 1987).

Inoculation of one of the herpesvirus isolates in 3 seronegative subadult harbour seals resulted in rapid antibody formation and mild infection without serious illness (Horvat et al. 1989).

Herpesviruses were considered of minor importance for the 1988 seal disease because (1) they were isolated in only a small percentage (1 to $20 \%$ ) of the freeranging seals, (2) neutralizing antibodies against the herpesvirus isolate were present in only $53 \%$ of the seals, (3) these viruses have low pathogenicity, and (4) vaccination with candidate vaccines did not protect the seals against the fatal disease (Frey et al. 1989 Horvat et al. 1989, Osterhaus et al. 1990, Have et al 1992). Presence of herpesviruses in seals from various areas is shown in Table 2.

Antibodies to European phocine herpesviruses have also been detected in sera of Antarctic Weddell seals Leptonychotes weddelli and crabeater seals (T.C. Harder, Hannover Veterinary School, Germany, pers comm.).

\section{Morbilliviruses}

The primary cause of the disease has been identified in all affected areas as a virus related but not identical to canine distemper virus (CDV) (Breuer et al. 1988a, Cosby et al. 1988, Hofmeister et al. 1988, Kennedy et al. 1988a, Osterhaus \& Vedder 1988, Liess et al. 1989a, b, Curran et al. 1990, Krogsrud et al. 1990, Have et al. 1992). The virus was identified in CDV neutralization tests (Breuer et al. 1988a, Hofmeister et al. 1988, Osterhaus \& Vedder 1988, Liess et al. 1989b,
Table 2. Identification of some bacteria, mycoplasma and viruses in harbour seals from various regions. $x=$ detected. - = not detected

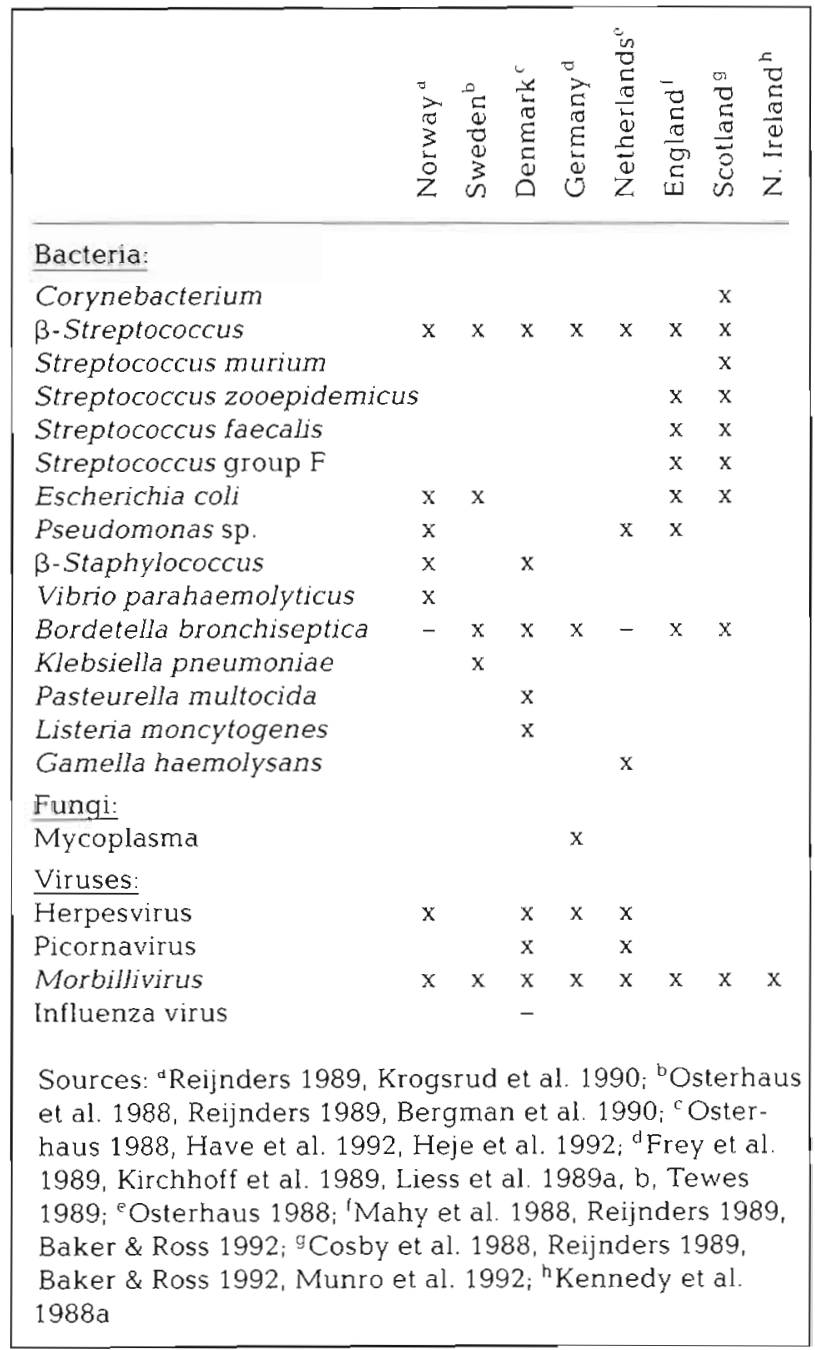

Krogsrud et al. 1990, Cornwell et al, 1992), immunofluorescence and immunoperoxidase staining of morbillivirus antigen in tissues of affected seals (Kennedy et al. 1988a, b. Have et al. 1992), and virus isolation (Breuer et al. 1988a, Hofmeister et al. 1988, Kennedy et al. 1988a, Liess et al. 1989b).

Inoculation of tissue suspensions from dead seals into specific-pathogen-free dogs caused a morbillivirus infection with mild clinical signs suggestive of canine distemper and presence of a morbillivirus in lung macrophages. Also, CDV-neutralizing antibodies were detected in the pathogen-free dogs $10 \mathrm{~d}$ after the inoculation (Osterhaus et al. 1988, Osterhaus et al. 1990). Jäger et al. (1990), in a similar experiment, could not confirm the pathogenicity of the seal virus in dogs but showed that the humoral response of the dogs could discriminate between isolates of the seal virus and CDV 
Confirmation that the primary cause of the seal disease was CDV or another morbillivirus was provided by experimental vaccination of seals against CDV. Two sham-vaccinated individuals died; the other 6 vaccinated seals survived a challenge with homogenates of tissues derived from diseased seals (Osterhaus et al. 1989a, Visser et al. 1989).

Mahy et al. (1988) showed by nucleic acid hybridization that the virus was probably a new member of the genus of Morbillivirus, different from both CDV and the other morbilliviruses. Cosby et al. (1988) confirmed that the seal-derived morbillivirus was antigenically more related to CDV than to other morbilliviruses, but that it had a nucleocapsid protein resembling some properties (e.g. molecular weight) of many rinderpest virus (RPV) strains. They also found that although the virus was more closely related antigenically to CDV than to measles or rinderpest viruses, it differed from CDV and RPV by epitopes on the N, F, P and H proteins. Since known strains of CDV have a high degree of antigenic conservation at these epitopes, these results indicated that the virus was distinct from CDV. On the basis of this variation from standard strains of CDV, Cosby et al. (1988) christened the new virus phocine distemper virus (PDV).

An isolate of PDV was used for comparative testing of neutralizing antibodies against CDV and PDV in sera from 57 dead or moribund seals at a German seal nursery (Liess et al. 1989c). The titres against PDV were invariably higher than against CDV, suggesting a novel morbillivirus distinct from CDV. Also the humoral response in 8 harbour seals inoculated with a low dose of virus isolate showed discrimination between PDV and CDV in neutralization tests and antibody-binding assay (Harder et al. 1990). Using polymerase chain reaction. Haas et al. (1990) showed that PDV was different from RPV, and Osterhaus et al. (1990) showed that PDV antibodies were not directed against measles virus by specific haemagglutination inhibition. The seal virus was characterized further by Bostock et al. (1990), who showed in neutralization tests and ELISA reactions that the antibodies in seal sera reacted 'more broadly with the morbilliviruses' than do sera raised against other members of the morbillivirus genus (e.g. peste-des-petits-ruminants and RPV). PDV isolates from Ireland, Denmark and Holland reacted identically with a panel of monoclonal antibodies against CDV and PDV. The results indicated that PDV isolates from the 3 areas were 'very closely related or identical' (Örvell et al. 1990, Cosby et al. 1988, Visser et al. 1990). Also, nucleic acid hybridisation and polymerase chain reaction analysis of PDV isolates from infected seals from throughout northern Europe showed that the infectious agent was identical in all studied seal herds (Barrett et al. 1992).
Conclusive evidence that PDV, CDV, measles and RPV are distinct viruses came from comparison of nucleotide sequences. The overall homology between PDV and CDV was approximately $70 \%$ at the nucleic acid and protein levels, and the homologies to measles and RPV were much poorer (Curran et al. 1990). PDV appeared to be as different from CDV as RPV is from measles, and it is unlikely that PDV developed from a recent mutation of CDV (Curran et al. 1990). The description of PDV as a new species in the genus Morbillivirus is now in progress, e.g. Rima et al. (1990), Haas et al. (1991), Harder et al. (1991).

\section{Other infectious agents}

In many cases, the final cause of death for seals infected with PDV was bacterial infection with one or more opportunistic pathogens. Unfortunately, the presence of bacteria and mycoplasma was not tested for or reported consistently in many studies. Nevertheless, there appear to be several bacteria which were important secondary pathogens in most areas (Table 2). In particular, Bordetella bronchiseptica, a bacterium which is indicative of CDV infections in dogs (West 1979), was commonly found (Table 2). In Denmark, it was isolated in 37 of 81 lungs (Heje et al. 1992) and, in northeast Scotland, it was found in the lungs of all 14 seals which had gross pathology indicative of PDV infection (Munro et al. 1992). The prevalence of Bordetella did, however, vary between different parts of the United Kingdom (Baker \& Ross 1992) and, although seen in seals from Sweden and Germany, was absent in samples from Norway (Krogsrud et al. 1990).

A virus tentatively classified as a picornavirus was isolated from the lung tissues of 20 of 22 seals sampled (Osterhaus 1988). Antibodies to canine parvovirus were equally abundant in diseased and non-affected seals (Osterhaus et al. 1990). Eye, throat, heart, brain, and lung tissue and nasal swabs from 40 seals found dead $(\mathbf{n}=123)$ in the German Wadden Sea were studied for the presence of mycoplasma (Kirchhoff et al. 1989). Eleven different mycoplasma strains were isolated, but it was concluded that these were secondary invaders (Stadtländer et al. 1989).

\section{DISTEMPER-LIKE VIRUSES IN MARINE MAMMALS}

\section{Tests for antibodies to CDV and PDV in pinnipeds}

CDV infections in dogs probably result in life-long immunity in recovered individuals (Appel 1987, Osterhaus et al. 1990). If this is also true of PDV infections in 
seals, tests for CDV-neutralizing antibodies will indicate whether or not CDV-like infections are present in pinniped populations (Table 3).

A survey of 134 serum samples collected between 1984 and March 1988 showed a pre-epizootic absence of CDV-neutralizing antibodies in European harbour seals (Osterhaus et al. 1988). Thirty of these samples were tested later for RPV-neutralizing antibodies, and 5 showed positive (Osterhaus et al. 1989d). A more sensitive ELISA-test showed 3 of these samples to be positive for RPV or CDV antibodies, or in the CDV test. However, none of the tested seals had developed distemper-like symptoms, and it was concluded that a morbillivirus with much lower pathogenicity had been present before the PDV infection in 1988. Other studies have shown that there is good maternal transfer of morbillivirus antibodies in both grey and common seals (Carter et al. 1992, Cornwell et al. 1992). Given that the samples in the study by Osterhaus et al. (1989d) were all from young pups at nursery stations, it is possible that the antibodies present were maternally derived. Consequently, the lack of disease symptoms in these pups may not be indicative that these are antibodies to another, less pathogenic, morbillivirus.

Morbillivirus antibodies were absent in samples taken from United Kingdom grey seals between 1985 and 1987, based both on ELISA (Carter et al. 1992) and virus-neutralisation (Cornwell et al. 1992) tests. However, samples taken during the autumn 1988 breeding season showed that almost all adult grey seals had seroconverted (Harwood et al. 1989, Carter et al. 1992; Table 3).

Pacific pinnipeds from the Bering Sea were tested for CDV-neutralizing antibodies, but none showed positive (Table 3; Osterhaus et al. 1988). In the Atlantic, harp seals Phoca groenlandica were considered possible vectors of the disease agent. Indirect immunofluorescense and ELISA tests of body fluids from 124 harp seals collected between 1.985 and 1987 from the East and West Atlantic (Fig 2) showed that up to $30 \%$ were positive (West Greenland; Table 3). After the epizootic in 1989 serum samples from harp seals collected from the West Ice and the Barents Sea, both part of the East Atlantic harp seal stocks (Fig. 2), showed a high (98\%) prevalence of PDV neutralizing antibodies (Markussen \& Have 1992). It was characteristic that the antibody titres were higher for PDV than for CDV and more seals were positive to the PDV-neutralization test than to CDV-neutralization tests or immunofluorescence tests.

Archival sera samples from several species occurring in the Western Atlantic were also tested using ELISA techniques (Henderson et al. 1992). These studies indicate that Canadian populations of harp seals, ringed seals Phoca hispida, grey seals and hooded seals Cystophora cristata have been exposed to morbilliviruses (Table 3).

In the Antarctic antibodies to CDV were detected in crabeater seals in 1989 (Bengtson et al. 1991). Crabeater seals had a mass die-off in 1955 but no viral agent was detected (Laws \& Taylor 1957). The crabeater seal sera showed higher titres when exposed against a CDV-strain than to a PDV-isolate, and this led Bengtson et al. (1991) to conclude that a CDV infection had been introduced into the Antarctic, probably by sled dogs.

Results of tests for CDV- or PDV-like antibodies in various pinnipeds are given in Table 3 but the specifics of these tests varied. Liess et al. (1989c) stressed the necessity of using a PDV-isolate when searching for antibodies against infections resembling the seal disease in 1988. Nevertheless, it is clear that CDV-like infections were present in a number of Atlantic and Antarctic pinniped populations, of several different species, before the epizootic in harbour seals began in the North Sea. At present PDV-like infections seem to be more common in harp seals than in any other pinniped except for the main victim of the epizootic in 1988: the harbour seal.

\section{Tests for antibodies to CDV in cetaceans}

While the seal epizootic raged in the North Sea, an unknown number of harbour porpoises Phocoena phocoena were washed ashore, and some were tested for presence of morbilliviruses. A morbillivirus antigen was detected in 6 harbour porpoises found dead on the coast of Northern Ireland, and the pathology of the porpoises was similar to that associated with the seal disease (Kennedy et al. 1988b, 1991). However, subsequent analyses using monoclonal antibodies suggest that the virus isolate from these porpoises is distinct from both PDV and CDV (MCCullough et al. 1991, Rima et al. 1992). CDV-antibodies were not detected in 5 harbour porpoises from the Kattegat in 1988 (P. Have, State Veterinary Institute for Virus Research, Lindholm, Denmark, pers. comm., Lindstedt 1990).

Serum samples from 13 bottlenose dolphins Tursiops truncatus, captured alive on the U.S. east coast in 1987 , were tested in CDV-neutralization tests (Geraci 1989a). Six dolphins had titres ranging between $1: 2$ and $1: 128$, but no CDV-like lesions or viruses were detected in any of the dolphins from the mass die-off during 1987-88 (Geraci 1989a). A mass die-off of a minimum of 400 striped dolphins Stenella coeruleoalba in the Western Mediterranean starting in July 1990 was caused by a morbillivirus (Domingo et al. 1990). How- 
Table 3. Presence of CDV-or PDV-neutralizing antibodies in various pinnipeds

\begin{tabular}{|c|c|c|c|c|c|}
\hline Species & $\begin{array}{l}\text { Year of } \\
\text { sampling }\end{array}$ & Area & $\begin{array}{l}\text { No. } \\
\text { tested }\end{array}$ & $\begin{array}{l}\text { No. } \\
\text { positive }\end{array}$ & Source \\
\hline $\begin{array}{l}\text { Harbour seal } \\
\text { Phoca vitulina }\end{array}$ & $\begin{array}{c}1984-88 \\
1988 \\
1988 \\
1989 \\
1990 \\
\text { Before } 1988 \\
1988-89 \\
1981-89 \\
1989 \\
1984-88 \\
1989\end{array}$ & $\begin{array}{l}\text { North Sea } \\
\text { West Atlantic } \\
\text { England } \\
\text { England } \\
\text { England } \\
\text { Northern Baltic } \\
\text { Northern Baltic } \\
\text { Southern Baitic } \\
\text { United Kingdom } \\
\text { Alaska } \\
\text { East Canada }\end{array}$ & $\begin{array}{r}134 \\
6 \\
32 \\
28 \\
14 \\
10 \\
14 \\
9 \\
56 \\
4 \\
11\end{array}$ & $\begin{array}{r}0 \\
3 \\
20 \\
3 \\
0 \\
0 \\
0 \\
1 \\
31 \\
0 \\
4\end{array}$ & $\begin{array}{l}a, b \\
c \\
d \\
d \\
d \\
e \\
e \\
e \\
f \\
a \\
d\end{array}$ \\
\hline $\begin{array}{l}\text { Grey seal } \\
\text { Halichoerus grypus }\end{array}$ & $\begin{array}{c}1980-81 \\
1989 \\
1985-87 \\
1988 \\
1988 \\
1988 \\
1989 \\
1981-89 \\
1990\end{array}$ & $\begin{array}{l}\text { Canada } \\
\text { East Canada } \\
\text { United Kingdom } \\
\text { England } \\
\text { Scotland } \\
\text { United Kingdom } \\
\text { United Kingdom } \\
\text { Baltic } \\
\text { Baltic }\end{array}$ & $\begin{array}{r}9 \\
24 \\
90 \\
16 \\
12 \\
73 \\
45 \\
30 \\
1\end{array}$ & $\begin{array}{r}3 \\
15 \\
0 \\
0 \\
0 \\
2 \\
43 \\
0 \\
1\end{array}$ & $\begin{array}{l}g \\
d \\
f, d \\
d \\
e \\
f \\
h \\
e \\
e\end{array}$ \\
\hline $\begin{array}{l}\text { Harp seal } \\
\text { Phoca groenlandica }\end{array}$ & $\begin{array}{c}1985-86 \\
1987 \\
1987 \\
1987 \\
1989 \\
1989 \\
\text { Before } 1988 \\
1988 \\
1971-80\end{array}$ & $\begin{array}{l}\text { West Greenland } \\
\text { Barents Sea } \\
\text { West Ice } \\
\text { Barents Sea } \\
\text { West Ice } \\
\text { Barents Sea } \\
\text { Kattegat } \\
\text { North Sea } \\
\text { Canada }\end{array}$ & $\begin{array}{r}40 \\
10 \\
46 \\
28 \\
37 \\
68 \\
1 \\
1 \\
10\end{array}$ & $\begin{array}{r}12 \\
1 \\
3 \\
0 \\
36 \\
67 \\
0 \\
1 \\
3\end{array}$ & $\begin{array}{l}\mathrm{i} \\
\mathrm{e} \\
\mathrm{j} \\
\mathrm{j} \\
\mathrm{j} \\
\mathrm{e} \\
\mathrm{e} \\
\mathrm{n} \\
\mathrm{g}\end{array}$ \\
\hline $\begin{array}{l}\text { Hooded seal } \\
\text { Cystophora cristata }\end{array}$ & $1983-84$ & Canada & 11 & 2 & $g$ \\
\hline $\begin{array}{l}\text { Ringed seal } \\
\text { Phoca hispida }\end{array}$ & $\begin{array}{c}1972 \\
1981-89 \\
1984-87 \\
1988 \\
\text { Before } 1988 \\
1984-88\end{array}$ & $\begin{array}{l}\text { Canada } \\
\text { Baltic } \\
\text { Greenland } \\
\text { NW Greenland } \\
\text { Svalbard and Norway } \\
\text { Alaska }\end{array}$ & $\begin{array}{r}3 \\
16 \\
90 \\
10 \\
29 \\
60\end{array}$ & $\begin{array}{l}2 \\
0 \\
4 \\
0 \\
0 \\
0\end{array}$ & $\begin{array}{l}g \\
\mathrm{e} \\
\mathrm{i} \\
\mathrm{k} \\
\mathrm{e} \\
\mathrm{a}\end{array}$ \\
\hline $\begin{array}{l}\text { Spotted seal } \\
\text { Phoca largha }\end{array}$ & $1984-88$ & Alaska & 8 & 0 & $\mathrm{a}$ \\
\hline $\begin{array}{l}\text { Bearded seal } \\
\text { Erignathus barbatus }\end{array}$ & $1984-88$ & Alaska & 5 & 0 & a \\
\hline $\begin{array}{l}\text { Steller sea lion } \\
\text { Eumatopius jubatus }\end{array}$ & $1984-88$ & Alaska & 12 & 0 & $\mathrm{a}$ \\
\hline $\begin{array}{l}\text { Ribbon seal } \\
\text { Phoca fasciata }\end{array}$ & $1984-88$ & Alaska & 4 & 0 & $\mathrm{a}$ \\
\hline $\begin{array}{l}\text { Walrus } \\
\text { Odobenus rosmarus }\end{array}$ & $1984-88$ & Alaska & 158 & 0 & a \\
\hline $\begin{array}{l}\text { Weddell seal } \\
\text { Leptonychotes weddelli }\end{array}$ & $1984-89$ & Antarctic & 24 & 0 & $a, l$ \\
\hline $\begin{array}{l}\text { Crabeater seal } \\
\text { Lobodon carcinophagus }\end{array}$ & 1989 & Antarctic & 96 & 32 & 1 \\
\hline $\begin{array}{l}\text { Leopard seal } \\
\text { Hydrurga leptonyx }\end{array}$ & 1989 & Antarctic & 3 & 2 & 1 \\
\hline $\begin{array}{l}\text { Baikal seal } \\
\text { Phoca sibirica }\end{array}$ & 1988 & Lake Baikal & 83 & 45 & $\mathrm{~m}$ \\
\hline \multicolumn{6}{|c|}{ 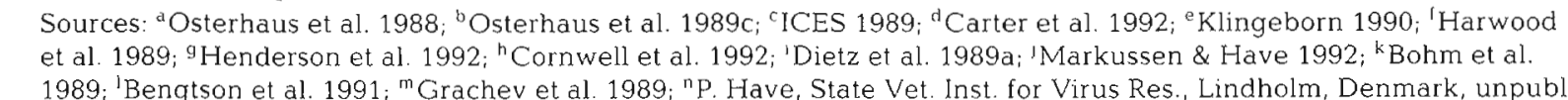 } \\
\hline
\end{tabular}




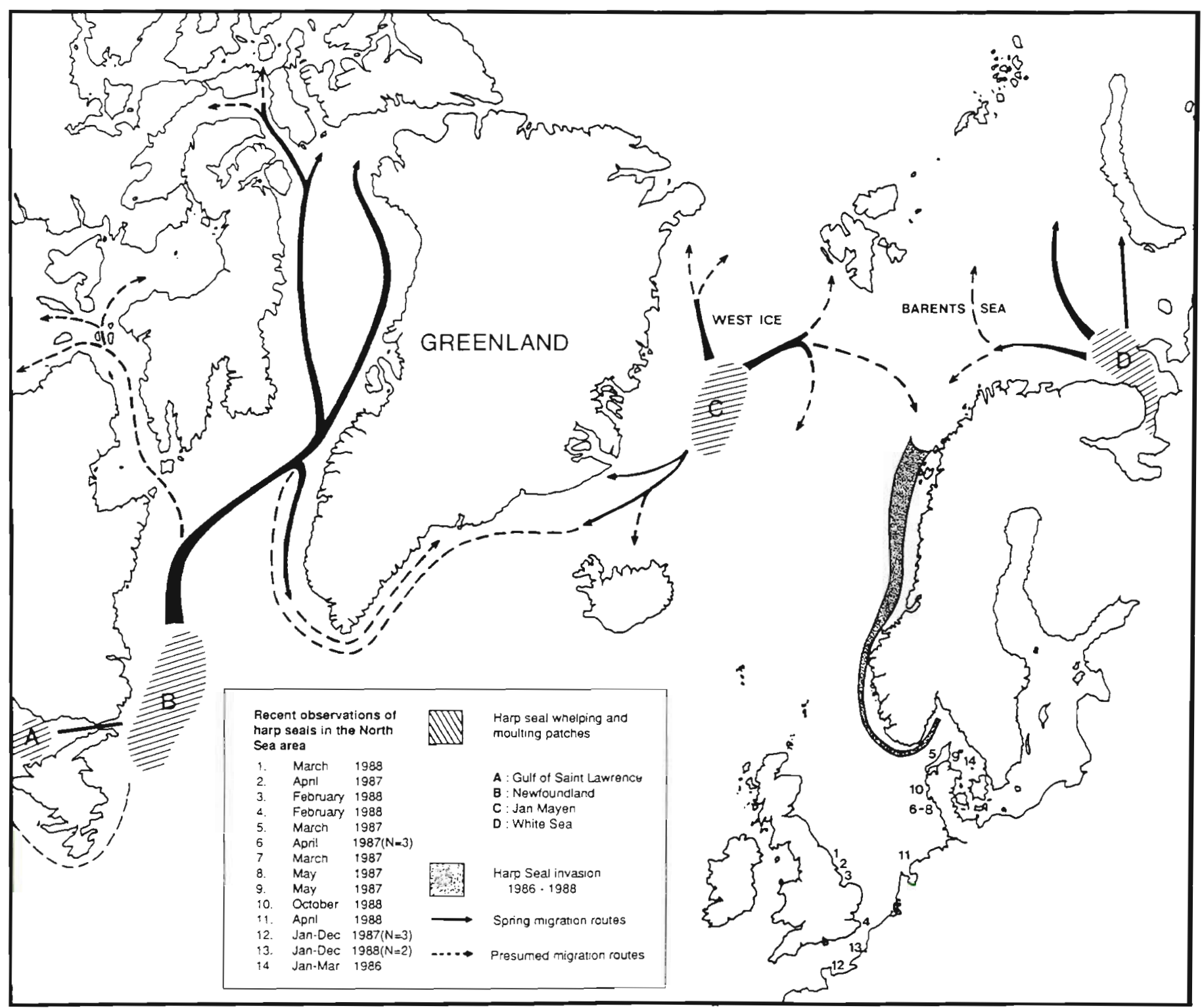

Fig. 2. Distribution and migration of harp seals in the Atlantic with localities of recent observations in the North Sea area indicrted. Observation nos. (1) to (4) are from Howes (1989). (5) to (9) from Larsen et al. (1987), (10) from P. Have, State Veterinary Institute of Virus Research, Lindholm, Denmark, pers. comm., (11) from M. Stede, Cuxhaven, Germany, pers, comm., (12) from Duguy (1988), (13) from Duguy (1989), and (14) from Klingeborn (1990)

ever, the virus involved has been described only in a preliminary way to date. Lesions in these dolphins were similar to those in North Sea harbour porpoises in 1988 (Kennedy et al. 1988b, 1991, Domingo et al. 1990)

No antibodies against CDV or PDV could be detected in virus neutralization tests of serum or plasma samples from 16 sperm whales Physeter macrocephalus killed in Iceland in 1982, 4 Icelandic killer whales Orcinus orca from 1981, 7 common dolphins captured in the Mexican Gulf during 1969 to 1985,174 and 42 samples from fin whales Balaenoptera physalus and sei whales Baldenoptera borealis killed in Iceland during 1973 to 1989 and 1982 to 1988, respectively (Svansson et al. 1991).

\section{The distemper disease in Baikal seals}

Just prior to the PDV epizootic among European harbour seals a similar disease occurred among Baikal seals Phoca sibirica in Lake Baikal. The epizootic in Lake Baikal began in autumn 1987 and lasted until October 1988, by which time 'several thousands of the 
80000 to 100000 seals in Lake Baikal had died (Grachev et al. 1989). The clinical symptoms were paralyzed hind extremities, opthalmitis, diarrhoea and convulsion of the hind flippers - all symptoms resembling those observed in the PDV infection in Europe (Grachev et al. 1989). The histopathological findings were also typical of those seen in the harbour seals: e.g. eosinophilic inclusion bodies in bladder epithelium, liver, kidneys, spleen, lungs and neurons of the brain and spinal cord (Grachev et al. 1989, Osterhaus et al. 1989b). Presence of a morbillivirus was shown by haemagglutination reactions with measles antigen, neutralization of a CDV vaccine strain, oligonucleotide probing, radioimmunometric assay and ELISA tests. Results showed that the majority of the seals had antibodies against CDV and that pathogen-free dogs developed CDV-neutralizing and ELISA antibodies within 12 d (Grachev et al. 1989, Osterhaus et al. $1989 b)$. Likhoshway et al. (1989) isolated the virus from Baikal seals and compared it to CDV isolated from infected dogs. After immunogold staining and electron microscopy they concluded that the seal virus was similar to CDV.

Three seals captured in Lake Baikal and introduced to a Japanese aquarium in May 1988 developed clinical symptoms similar to those associated with PDV and those described from Lake Baikal (Nunoya et al. 1990). All died within $18 \mathrm{~d}$, but before dying they infected 3 Baikal seals already residing at the aquarium. The latter developed the clinical signs within 11 to $16 \mathrm{~d}$. One died $22 \mathrm{~d}$ later, and the remaining 2 were treated medically and recovered after 22 to $27 \mathrm{~d}$ with clinical signs. Histopathological characteristics observed in European harbour seals in 1988 and in Siberian Baikal seals in 1987 were prominent in all seals that died: e.g. acute interstitial pneumonia, inclusion bodies and depletion of lymphocytes. Serum from the 2 infected but medically treated seals had high titres of CDV-neutralizing antibodies (Nunoya et al. 1990).

The viruses isolated during the seal disease in 1987 in Baikal seals and in 1988 in harbour seals were tested for differences by comparing neutralizing antibody titres of the 2 seal viruses with that of CDV, and by assessing their reactivities in indirect ELISA tests with CDV-reactive monoclonal antibodies (Osterhaus et al. 1989c, Visser et al. 1990). On the basis of these tests, it was concluded that the virus that infected the Baikal seals was more closely related to CDV than to any other morbillivirus, including PDV (Osterhaus et al. 1989 c, Visser et al. 1990). This conclusion was later confirmed as a result of polymerase chain reaction analysis (Barrett et al. 1992).

The similarity between the Baikal seal virus and CDV suggests an epizootiological link to a simul- taneous outbreak of CDV in dogs, some of which had 'close contact with seals' (Grachev et al. 1989). This is the first confirmation that CDV can infect pinnipeds.

\section{ASPECTS OF HEALTH BEFORE THE EPIZOOTIC}

It has been suggested that vulnerability to infection by PDV is affected by parasite infestation or pollution (e.g. Eis 1989)

\section{Parasites in alimentary tracts}

Three species of nematode parasites are found frequently in European harbour seals: Pseudoterranova decipiens (cod worm), Contracaecum osculatum, and Anisakis simplex (herring worm) (Young 1972, Bjørge 1987, Lick 1989, Claussen et al. 1991).

The harbour seal is one of the final hosts for cod worm, which is the most common anisakine species in harbour seals in European waters. Occurrence of this parasite increases with age (Lick 1989, Lunneryd 1991). and varies insignificantly between areas. In the Wadden Sea, $96 \%$ of seals older than 2 yr were infected (Lick 1989), whereas a prevalence of $65 \%$ was found in the Kattegat-Skagerrak (Lunneryd 1991) In British waters a similar high infection rate $(80 \%)$ was reported in older seals (Young 1972). The prevalence of Contracaecum osculatum is reported to be $28 \%$ in the Wadden Sea (Lick 1989), close to $100 \%$ in British waters (Young 1972), and $45 \%$ in the KattegatSkagerrak (Lunneryd 1991). Data from the Norwegian coast indicate a comparatively low prevalence (Bjørge 1987). There seem to be only small effects of cod worm and C. osculatum on the health of their hosts, but some studies indicate that both species might contribute to development of gastric ulcers in harbour seals (McClelland 1980).

Juvenile herring worms are widely distributed in pinnipeds, but mature specimens are reported only occasionally in seals. Thus seals are probably of minor or no importance to the spread of Anisakis simplex (e.g. Machida 1971, Smith \& Wootten 1978, Bjørge 1987, Lick 1989, Lunneryd 1991). Gastric ulcers are often found in association with herring worm infestations in both harbour seals and harbour porpoises (Smith 1989). Herring worm and the associated gastric ulcers have not been reported from the Baltic, probably because of the lack of suitable intermediate invertebrate hosts there (Lunneryd 1991).

Studies on the occurrence of trematodes, cestodes and acanthocephalans in harbour seals from Niedersachsen (Fig. 1) showed infestation rates of $71 \%$ for 
Cryptocotyle lingua, $36 \%$ for Phagicola septentrionalis, $32 \%$ for Diphyllobothrium cordatum, and D. strumosum and $95 \%$ for Corynosoma strumosum (Strauss et al. 1991). These species show a considerable variation in prevalence between regions. The prevalence of C. strumosum was $25 \%$ in the southern Kattegat (Lunneryd 1992).

\section{Other parasites}

In the Wadden Sea, the lungworm Otostrongylus circumlitus was reported in $26 \%$ of 115 studied seals, whereas $32 \%$ were infested by heart worm Dipetalonema spirocauda (Breuer et al. 1988b, 1988d, Claussen et al. 1991). Parafilaroides gymnurus was detected in $27 \%$ of the studied lungs and in addition in livers of 2 seals, and in the pulmonary artery in one case (Claussen 1990, Schumacher et al. 1990). In 22 of 101 necropsied seals, massive pulmonary and cardial parasitic infestations had led to chronic pulmonary disease and severe pulmonal and mediastinal emphysemas, causing pneumothorax or phytothorax as immediate cause of death. Most seals were afflicted in varying degrees by lice Echinopthirius horridus (Schumacher et al. 1990), which is assumed to be the intermediate host of heart worm (Geraci et al. 1981).

In the Irish Sea 12 of 108 seals examined had heart worms in the right ventricle and pulmonary artery, and nasal mites Halarachne halichoeri were seen commonly in nasal cavities (Kennedy et al. 1989b). Many of these seals were also infected with the lungworm Otostrongylus circumlitus. Around Scotland nasal mites were observed in 2 seals and parasitic bronchitis caused by $O$. circumlitus was a feature in the younger age groups where it appeared to cause greater problems than Parafilaroides sp. (Munro et al. 1992). In the Kattegat-Skagerrak, the $O$. circumlitis, lice and nasal mites were not observed, but heart worm was reported in 18 of 158 seals examined, with a range of 1 to 30 specimens per infested seal (Lunneryd 1992). The low abundance and infestation rate indicate that no major detrimental effects can be expected on the seals in this area.

Thus, infestation of parasitic stomach nematodes did not substantially affect the mortality of various seal stocks, but in some areas massive infestations of lung and heart worms could have aggravated the disease.

\section{Pathological changes in seal skulls}

The basic structure ('blueprint') of bony tissue is formed in a process where calcium salts are mineralized around a collagen matrix. The continuous pro- cess of bone formation and demineralization in living animals is normally adjusted to the required stability of bones. Abnormal changes in structure or calcium content may be caused by deficiencies or hormonal imbalance (DeLellis 1989). Furthermore, structural changes of matrixes can also result in deformation of bones.

In a pilot study of 75 skulls of harbour seals from the German coast, $11 \%$ had severely increased porosity, whereas $48 \%$ were slightly but clearly different from normal skulls (Stede \& Stede 1990). In one third of the material, bone lesions of varying severity were present. Pathological changes were also studied in 199 skulls from adult harbour seals collected along the Swedish coast. These were compared with 43 skulls collected in the period 1835 to 1935. Mild lesions were found in a significantly higher frequency in the recent material and severe loss of bone tissue occurred only in the recent material (Mortensen et al. 1991). The lesions were characterized by loss of alveolar bone of the jaws, often manifested as bone defects in the mandible or maxilla. Similar and more severe changes were previously described in grey seals from the Baltic (Bergman et al. 1986). Another type of lesion, characterized by disturbance of the contour of the alveolar bone (alveolar exostosis), also showed significantly higher prevalence in the recent sample.

In a study of developmental stability of grey seal skulls from the Baltic, it was found that, compared with material from before 1950, the more recent material (after 1960) showed a statistically significant change in the phenotype structure (Zakharov \& Yablokov 1990). In harbour seals from Germany, $59 \%$ of studied individuals showed some kind of deformation or abnormality (Stede \& Stede 1990)

Osteoporosis and lesions belong to the complex of disturbances in reformation of bone tissue. The assumed connection with hormonal imbalance (hyperadrenocorticism) suggests osteodystrophia as a cause for osteoporosis (Bergman \& Olsson 1986, Bergman et al. 1986). In hyperadrenocorticism (Cushing's disease) osteoporosis is part of the spectrum of disease symptoms and lesions observed both in animals (e.g. Feldman 1983, Scott 1979) and man (e.g. Sommers 1977, DeLellis 1989\}.

Hormonal imbalance has been discussed by several investigators as an effect of contamination with polychlorinated biphenyls (PCB) (Bergman et al. 1986, Stede \& Stede 1990). By their basic chemical structure, PCBs could interfere in the regulatory mechanisms of steroid hormones (e.g glucocorticoid) (Safe 1984). Hypertrophy of glucocorticoids depresses formation of collagen, leading to a higher degree of porosity of bones due to lack of collagen matrixes. 


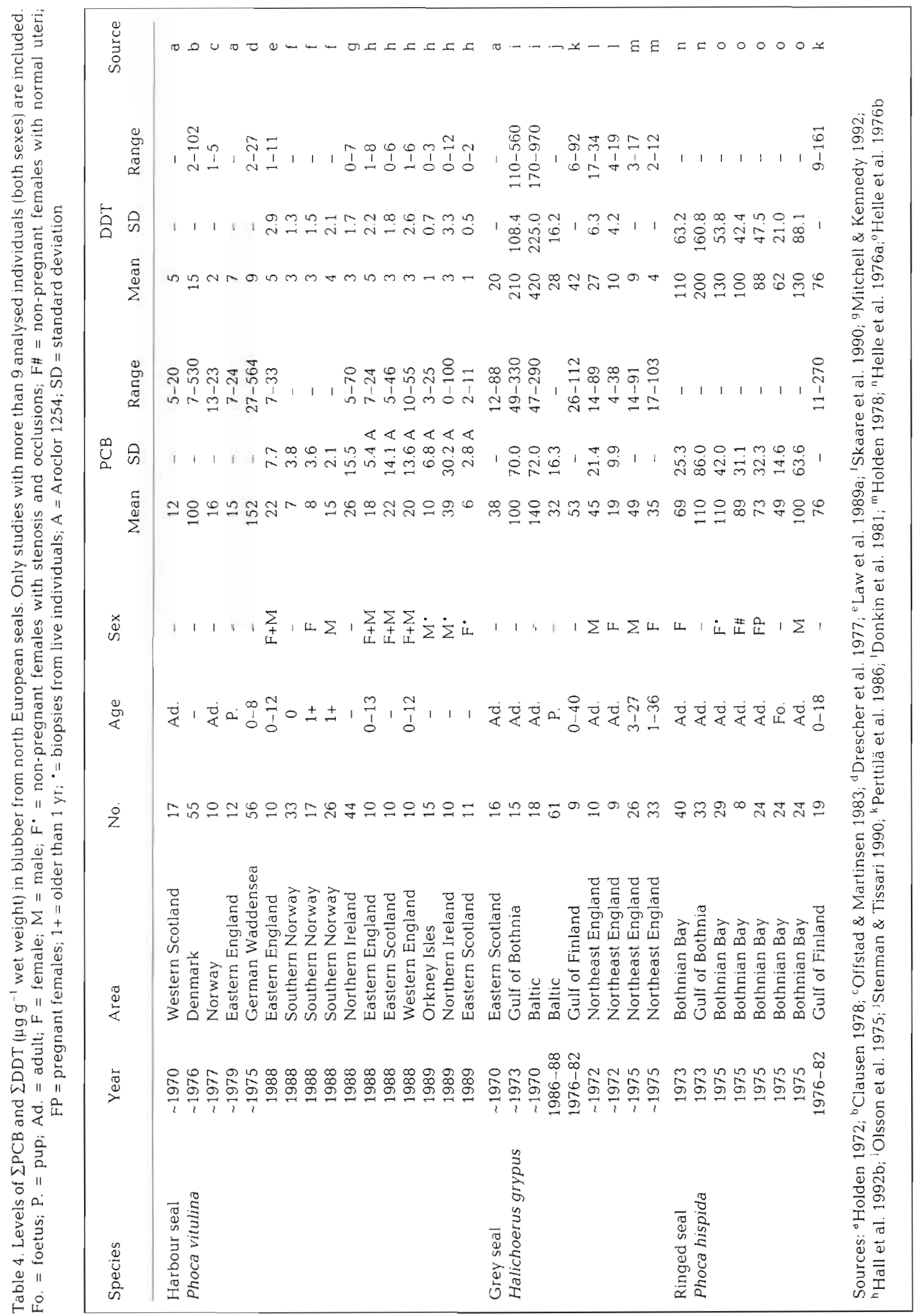




\section{Contaminant levels}

Levels of contaminants are not always comparable because of differences in sampling and methods of analysis. However, it is evident that the highest levels of PCB have been found in harbour seals from the German Wadden Sea and in grey seals from the Baltic in the 1970's with levels of ca $150 \mu \mathrm{g} \mathrm{g}^{-1}$ (Table 4). For pesticides such as DDT, the Baltic, the Gulf of Bothnia and the Bothnian Bay were the most polluted areas in the same period, with means in grey and ringed seals from 420 to $88 \mathrm{\mu g} \mathrm{g}^{-1}$, descending in the geographical order given (Table 4). In the Wadden Sea, Reijnders (1980) found a gradient in PCB levels in harbour seals from the Danish to the Dutch Wadden Sea, with increasing levels towards the Dutch Wadden Sea.

Helle et al. (1985) showed a reduction in DDT and $\mathrm{PCB}$ levels in yearlings of grey seals and ringed seals from the Gulf of Finland and the Bothnian Bay over the period 1976 to 1983. This reflects the decrease in PCB and DDT in Baltic marine biota in the same period (Olsson \& Reutergårdh 1986)

Analyses of organochlorines were carried out on seals that died during the epizootic in England, Northenn Ireland and Norway but values were low, i.e. in the range of 0.14 to 100 and 0.1 to $12.1 \mathrm{mg} \mathrm{g}^{-1}$ wet weight (w.w.) for PCB and DDT, respectively (Table 4; Law et al. 1989a, Skaare et al. 1990, Mitchell \& Kennedy 1992, Hall et al. 1992b). These results were in the lower range of previously reported values from the North Sea, Kattegat and Baltic Sea (Table 4; Reijnders 1980 , Donkin et al. 1981, Perttilä et al. 1986, Oehme et al. 1988). The levels also were equivalent to or lower than those in the normally breeding population of California sea lions Zalophus californianus which had mean PCB and DDT ranges of 12 to 25 and 51 to $203 \mathrm{mg} \mathrm{g}^{-1} \mathrm{w}$. W., respectively (DeLong et al. 1973).

Heavy metals constitute a group of pollutants that has been extensively studied in European seals (e.g. Henrikson et al. 1969. Heppleston \& French 1973, Roberts et al. 1976, Drescher et al. 1977, Caines 1978, Harms et al. 1978, Duinker et al. 1979, Reijnders 1980, Perttilä et al. 1986, Skaare et al. 1990, Law et al. 1991). However, the etiology of the seal. disease does not fit with clinical findings of intoxication by heavy metals such as mercury, cadmium and lead.

Information on radionuclides in pinnipeds is limited. Reijnders (1990) cites unpublished results from Drescher for ${ }^{134} \mathrm{Cs} /{ }^{137} \mathrm{Cs}$ to be around 3 to $4 \mathrm{~Bq} \mathrm{~kg}^{-1}$ body weight of harbour seals in the Wadden Sea. Anderson et al. (1990) found that levels of ${ }^{137} \mathrm{Cs}$ in muscles from 3 British grey seals ( 2 pups and an adult female) varied between 6.4 and $27.5 \mathrm{~Bq} \mathrm{~kg}^{-1}$, whereas levels of ${ }^{124} \mathrm{Cs}$ were significantly lower These levels are much lower than observed ${ }^{137} \mathrm{Cs}$ values of 2 grey seals (male $1.4 \mathrm{yr}$; female 8 to $10 \mathrm{yr}$ ) from the Bothnian Sea, which had 146 and $157 \mathrm{~Bq} \mathrm{~kg}{ }^{-1}$, respectively. A single 1 yr old ringed seal from the same area had a level of $331 \mathrm{~Bq}$ $\mathrm{kg}^{-1}$ body weight (A. Bergman, Swedish University of Agricultural Sciences, Uppsala, Sweden, pers. comm.). None of the reported levels are alarming compared to levels in some terrestrial mammals.

\section{POSSIBLE TRIGGERING MECHANISMS}

\section{Pollution}

A number of authors have discussed the possible role of contaminants in the seal epizootic (e.g. Brouwer et al. 1989, Dietz et al. 1989b, Eis 1989, Law et al. 1989a, 1989b, Simmonds \& Johnston 1989, Harwood \& Grenfell 1990).

When the seal plague started in April 1988 anthropogenic factors were șuspected as being responsible for the events. The large number of abortions was reminiscent of the many premature births of sea lions observed in southern California beginning in 1968. The fact that sea lions which aborted had PCB and DDT fractions in the blubber that were, respectively, 6.6 and 8.0 times higher than those found in normally whelping females inspired the belief that these substances were responsible for the high incidence of abortions (DeLong et al. 1973). Subsequent research on a larger sample revealed an imbalance in the atomic ratio of $\mathrm{Hg}-\mathrm{Br}-\mathrm{Se}$ and a high incidence of $L e p-$ tospira infections, thus illustrating the complexity of the problem of assessing cause-and-effect relationships (Gilmartin et al. 1976, Martin et al. 1976).

Later in 1988, the deaths of juvenile and adult harbour seals, which was not observed in California sea lions, indicated that a viral infection rather than organochlorines (or other pollutants) was the primary cause of the seal disease. The timing of the outbreak would have required that these compounds be mobilized to functionally toxic levels within a synchronized time-pulse. This is an unlikely scenario for substances that have been more or less constantly present in the environment and body tissues of seals for decades, unless something had triggered their release from fat reserves by first debilitating the animals (see also Geraci 1989a). Although the acute toxicity of a pollutant can be ruled out as a proximate cause of the seal deaths, it remains a possibility that indirect and immunosuppressive effects of organochlorines may have made seals more susceptible to PDV infection.

The levels of PCBs represent the sums of 209 theoretically possible isomers and congeners with differerent toxic and biological response. Among these isomers and congeners, 20 attain coplanarity and are 
approximate isostereomers of the highly toxic $2,3,7,8$ tetrachlorodibenzo-p-dioxin $\left(\mathrm{T}_{4} \mathrm{CDD}\right)$ and $2,3,4,7,8$ pentachlorodibenzofuran ( $\mathrm{P}_{5} \mathrm{CDF}$ ) and hence elicit similar toxic and biological responses (Tanabe 1988). These congeners have proven less toxic to guinea pigs. but the fact that coplanar PCBs are present at much higher levels than dioxins and furans makes them of similar concern (Tanabe 1988).

Wasserman et al. (1979) demonstrated an increase in the vulnerability of laboratory rats to infections when exposed to specific PCBs. Bergman \& Olsson (1985) suggested that PCBs and other organochlorines were associated with a disease complex in Baltic grey and ringed seals. Among the different lesions observed, uterine stenosis and occlusions, uterine tumors, intestinal ulcers, bilateral adrenocortical hyperplasia, arteriosclerosis and glomerulopathy were common. Common lesions in integuments were deformations and fractures of the claws. In a few cases these were regional skin changes similar to those present in endocrine dermatopathy. The adverse effect of PCBs on reproduction is believed to be one of the main reasons for the decrease of seal stocks in the Baltic (Olsson et al. 1975, Helle et al. 1976a, b). Uterine occlusions or stenose which severely affect fertility were found in $30 \%$ of adult grey seals and $70 \%$ of adult ringed seals. Both $\mathrm{PCB}$ and DDT are known to interfere with the hormonal cycle (Peakall 1967, Örberg et al. 1972, Örberg \& Kihlström 1973, Örberg \& Lundberg 1974) although DDT has been found to have little influence on the reproduction of mink (Platonow \& Karstad 1973, Aulerich \& Ringer 1977, Jensen et al. 1977, Bleavins et al. 1980). Reijnders (1986) showed experimentally that captive female adult harbour seals fed PCB-contaminated fish experience hormonal disturbances and reproductive failures.

Brouwer et al. (1989) studied effects of PCB on harbour seal endocrinology by comparing a group of 12 females fed contaminated fish from the Wadden Sea with an equally large group fed non-contaminated fish over a period of $2 \mathrm{yr}$. They found drastically reduced levels (30 to $55 \%$ ) of plasma retinol and thyroid hormone in the test group. The presumed resulting vitamin A deficiency was suggested to cause retarded growth, reproductive disorders and other pathological changes. Brouwer et al. (1989) also suggested a possible link to the seal epizootic since vitamin A plays an important role in the immune response and vitamin $A$ deficiency could result in increased susceptibility to microbial infections. In fact, Schumacher et al. (1990) found 'disturbed thyroid function' in 2 of 6 examined seals from the seal epizootic.

In studies of harbour seals which survived the epizootic, levels of certain PCBs in blubber biopsies were significantly related to blood thymulin concentrations when time since exposure to PDV was also taken into account (Kendall et al. 1992).

In the United Kingdom, Hall et al. (1992b) also compared organochlorine (DDTs and PCBs) concentrations in the blubber of seals found dead during the disease outbreak with levels in biopsies taken from survivors during the following spring. For most of the compounds analysed, organochlorine levels were significantly higher in seals which died. These data are therefore consistent with the hypothesis that seals with high organochlorine burdens may have been more vulnerable to PDV infection. However, sampling variation and changes in body condition may also have contributed to these differences and further work is required before firm conclusions can be drawn (Hall et al. 1992b).

Dietz et al. (1989b) listed several previous incidents of mass mortality, some with a similar etiology, from times before organochlorines were introduced and from areas with low input of pollutants. The CDV outbreak among high Arctic sled dogs had mortalities of up to $80 \%$ (Bohm et al. 1989). An immunosuppressive effect of organochlorines in the sled dogs has not been considered although organochlorines are present in dog food at levels comparable to European fish (e.g. Addison \& Smith 1974, Addison \& Zinck 1986, Muir et al. 1988, Muir et al. 1990). Also, distemper-like diseases have a long record in Greenlandic sled dogs (Bohm et al. 1989).

During late winter and spring of 1988 the Kattegat, Skagerrak and North Sea experienced unusual blooms of both toxic and nontoxic algae, sustained by eutrophication and a mild wet winter (Rosenberg et al. 1988). The algal toxin killed large numbers of benthic invertebrates and fish. This ecological disturbance has occurred annually, although in less pronounced forms, over almost a decade (e.g Edler 1986, Baden et al. 1990). The deaths of 14 humpback whales Megaptera novaeangliae in Cape Cod Bay (Massachusetts, USA) in 1987 showed that phytotoxins could have a fatal effect on marine mammals (Geraci et al. 1989). The whales died after consumption of Atlantic mackerel Scomber scombrus containing saxitoxin, a dinoflagellate neurotoxin responsible for paralytic shellfish poisoning in humans. Brevetoxin produced by Ptychodiscus brevis, Florida's 'red tide' organism, was found in dolphin livers at levels that cause human illness, among bottlenose dolphins that died along the U.S. east coast during 1987-88 (Geraci 1989a, b). The seals that died in the PDV epizootic usually had empty stomachs indicating that they had not fed recently and analysis of the scarce remains in stomachs indicated no evidence of saxitoxins (K. Granby, Danish Environmental Research Institute, Copenhagen, Denmark, pers. comm.). 
In conclusion, the eruption, development and dynamics of a distemper-like seal disease could occur without a linkage to pollutants. Nevertheless, organochlorines may have been present at immunosuppressive levels in seals affected by the 1988 European seal epizootic, and these may have contributed to the development of the disease.

\section{Crowding and over-population}

Many European harbour seal stocks have been increasing since the 1960s (e.g. Heidemann 1987. Stede 1987. Heide-Jørgensen \& Härkönen 1988), and this fact led to speculations that the epizootic could have been at least partially due to 'over-population'. This argument presupposes that one or several resources are limiting for the growth of the population. Such resources could be food or space at haul-out sites used for reproduction. In most areas in Europe, harbour seal stocks have been increasing steadily and no signs of density-dependent regulation on population growth were noted until 1988 (Heide-Jørgensen \& Härkönen 1988). Furthermore, most of the seals found dead during the epizootic were in normal nutritive condition (Härkönen \& Heide-Jørgensen 1990b), indicating that availability of food was not a limiting factor.

However, in an epizootiological context, density of pinnipeds is determined not only by population size but also by the crowding at haul-out sites (Fig. 3). Such crowding is itself affected by the number and area of haul-out sites, population size, and weather factors that periodically provide favourable conditions for hauling out. It is intuitively acceptable that the number of contacts between individuals is larger in dense herds where seals are huddling together on limited space. This is a function of seals hauled-out per area rather than a function of number of seals in the afflicted herds. Increased number of contacts between individuals increases dispersal rates by increasing the infection rate and by elevating the dose of infective viral particles received by each individual to threshold levels. Seals may seroconvert after receiving a low dose of infectious agents (see also Harder et al. 1990).

The disease developed identically in small and large herds from the Kattegat-Skagerrak, and in some small seal herds in the Baltic (Heide-Jørgensen \& Härkönen 1992). Other herds may have escaped the disease in 1988, e.g. some in the Baltic, Iceland, northern Norway, while others had a low mortality, e.g. in Scotland. The reduction in the opportunities of lateral spread of the virus in small and dispersed seal herds may explain why some herds had a significantly lower epizootic intensity. Also, the crowding on the few undisturbed haul-out sites may have aggravated the epizootic.
The other seal species frequently infected by morbilliviruses - crabeater seals, grey seals and harp seals - are both gregarious and form whelping patches. However, their whelping patches are not as dense as those seen for European harbour seals during the 1980s (Fig. 3)

Lavigne \& Schmitz (1990) found that in previous incidents of mass mortalities in pinnipeds, unseasonally warm weather prevailed prior to most mass die-offs. Gorham (1966) and Appel (1987) noted for dogs that the risk of infection by CDV increases with the density of the population, and this results in increased numbers of incidents during the cold season of the year. This could be explained either by a tendency to huddle together for warmth or by increased susceptibility of the respiratory epithelium during cold months.

In some areas, pinniped haul-out behaviour is related to changes in temperature. However, the influence of temperature only appears to be marked in extreme conditions. On Sable Island (Nova Scotia, Canada), for example, harbour seals rarely come ashore when windchill-corrected temperatures fall below $-15^{\circ} \mathrm{C}$ (Boulva \& McLaren 1979). In more temperate conditions, such as those found throughout the North Sea, temperature variations explain little of the variation in the number of seals present at haul-out sites (Schneider \& Payne 1983, Kreiber \& Barrette 1984). Seals haul-out throughout the year in these areas, and threshold values for an expansion of the 1988 epizootic were much lower than the size of most of these winter groups (Heide-Jørgensen \& Härkönen 1992). Warm weather is therefore unlikely to have enhanced the chance of an epizootic through its effects on haul-out densities.

\section{Vectors of morbilliviruses}

During 1986 to 1988 the North Sea was invaded by harp seals from the Northeast Atlantic and it has been suggested that migrating harp seals were a vector of PDV (Goodhart 1988, McGourty 1988, Wiig 1988). One harp seal was found dead in the Wadden Sea of Niedersachsen in April 1988 (Fig. 2; M. Stede, Cuxhaven, Germany, pers. comm. and another one with a high antibody titre against PDV was found on the west coast of Jutland (Denmark) in October 1988 (Fig. 2, P. Have, State Veterinary Institute for Virus Research, Lindholm, Denmark, unpubl. data) but there is no conclusive evidence that harp seals were in contact with the harbour seals in the Kattegat-Skagerrak or the North Sea in 1988 (see also Howes 1989). Harp seals are frequently infected by PDV as revealed by the presence of antibodies but it is not known whether the infections causes any diseases in the seals. Trans- 


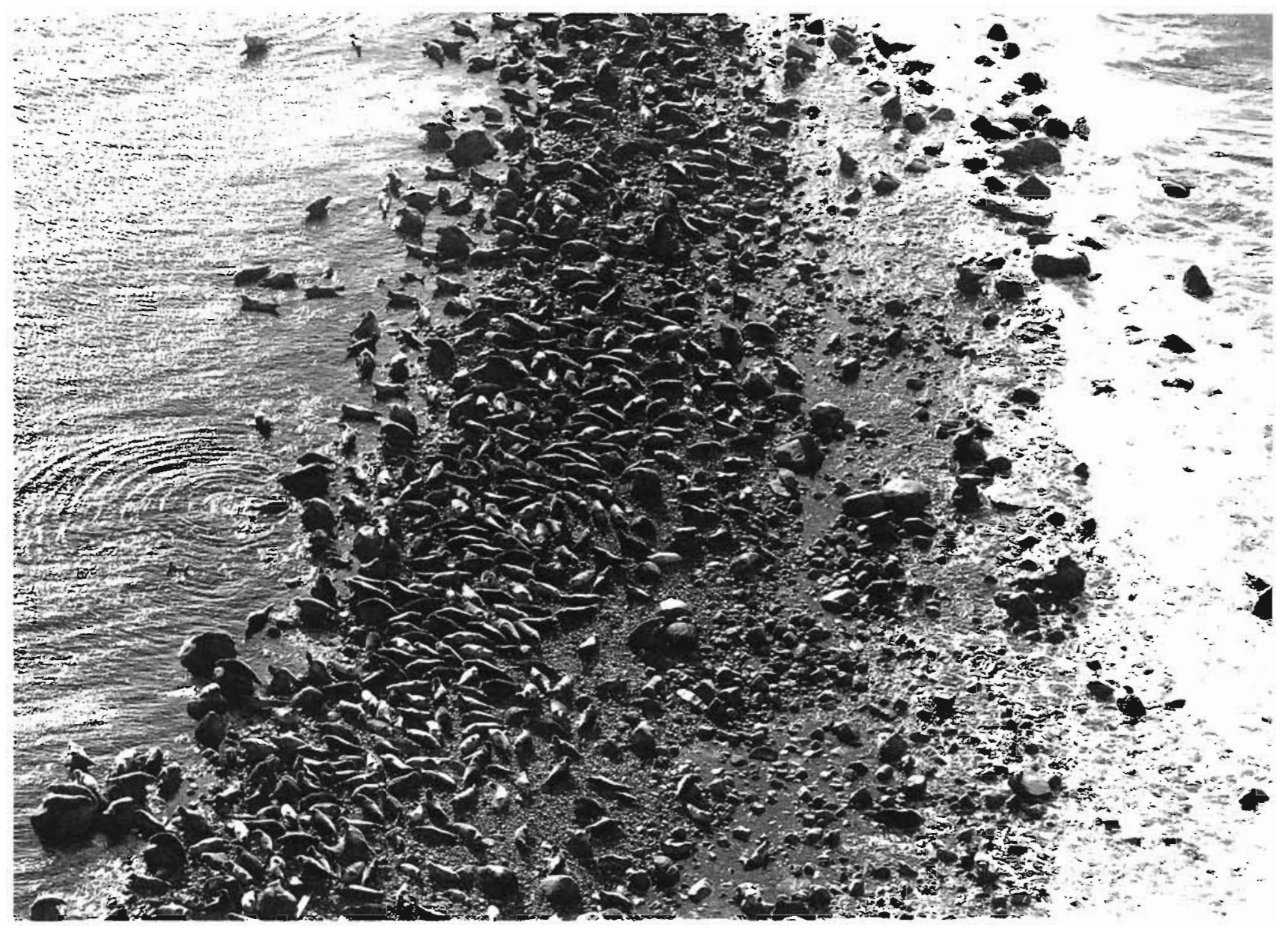

Fig. 3. Harbour seals congregating at the haul-out site of Hesselø, central Kattegat, in August 1987. In the years before the epizootic about 1000 seals used to haul-out onto a stone reef of less than $2000 \mathrm{~m}^{2}$. Could high haul-out densities caused by large population size relative to available haul-out space and an unusually warm winter have provoked or exacerbated an epizootic among the seals? (Photo: Danbiu ApS.)

mission of PDV is most likely by aerosols during acute infections of perhaps 2 wk (Appel 1987, Harder et al. 1990, Visser et al. 1990).

A morbillivirus infection has been detected in harbour porpoises and, because of their supposed migratory behaviour, they have also been proposed as a vector (Kennedy et al. 1988b, Kennedy 1990). Data on porpoise movements and contacts with seals in the North Sea area are too meagre to confirm this hypothesis (Kennedy et al. 1989a, Klinowska 1989). Furthermore, evidence now suggests that the infection in porpoises was by a different morbillivirus (Rima et al. 1992).

Sled dogs in northern Canada and Greenland experienced a severe epizootic caused by CDV infections during October 1987 to February 1988 (Leighton et al. 1988, Bohm et al. 1989). The primary infectious agent was identified as CDV by virus isolation and neutralization tests, and it was suggested that infected migrating arctic foxes Alopex lagopus had transmitted the CDV infections in the high Arctic (Bohm et al. 1989). The virus isolated from sled dogs was immunologically more closely related to CDV than to PDV (Orvell et al. 1990). The virus isolated from Baikal seals (see section on distemper disease in Baikal seals) was antigenically more similar to CDV than to PDV, and we therefore conclude that no epizootiological links exist between these CDV outbreaks and the PDV infection in the North Sea harbour seals. Nevertheless, the diseases in sled dogs and Baikal seals may well be linked, as both these species may have contact with arctic foxes or wolves, the presumed main reservoirs of CDV in the high Arctic (Bohm et al. 1989, Stephenson et al. 1982).

Virus isolates from a distemper outbreak in Danish mink Mustela vison in 1989 reacted identically to PDV isolates in tests with monoclonal antibodies directed against CDV and PDV (Örvell et al. 1990). However, 
another morbillivirus isolate derived from Mustelidae from a coastal area of northern Germany could be antigenically distinguished from 16 PDV-isolates (Harder et al. 1991). Inoculation of lung homogenates from diseased Danish seals in mink showed that the virus provoked a disease resembling canine distemper (Blixenkrone-Moller et al. 1989). Evidently, the sealderived virus may infect mink, but also the opposite possibility can not be ruled out' (Örvell et al. 1990).

\section{CONCLUSIONS}

Considerable new information has been gained since the seal epizootic began in 1988. Although much still can be learned, a number of fundamental questions on the disease are now solved.

(1) The etiology of the seal disease is well described from most areas (except the northern isles of Scotland), and the pathological and virological findings are in good concordance from all studied seal groups. The descriptions vary in detail but render little doubt that the disease had identical characteristics for all afflicted groups, and that a highly contagious virus, phocine distemper virus (PDV), from the genus of Morbillivirus was the primary cause of the disease.

(2) Studies of the antigenic and biochemical properties of PDV indicate that it is a newly recognised morbillivirus different from canine distemper virus (CDV), measles, rinderpest and peste-des-petite-ruminants. It has also been demonstrated that PDV is not a simple mutation of CDV or another morbillivirus, but rather a virus specific for marine mammals, that, on an evolutionary time-scale, may have developed from CDV.

(3) Apart from PDV a number of viral and bacterial agents, as well as parasites, have been identified in the dead seals but none of them seem to be of primary importance for the development of the disease syndrome However, the defence and control of normally trivial bacterial infections may be hampered in seals infected by the immunosuppressive PDV infections.

(4) The high intensity and mortality of the epizootic can be explained by the fact that PDV was introduced into a naive population with limited or no specific immunity to the virulent pathogen. No contributory external factors are necessary for explaining the severity of the distemper-like disease, but synergistic effects of pollutants cannot be ruled out and should be studied experimentally.

(5) Bone lesions and skull deformations indicate that parts of the European seal stocks may have been affected by hormonal imbalance before the epizootic. There are also indications in some areas that diseased seals carried higher levels of organochlorines than survivors
(6) The cause behind the differences in mortality rates in different parts of the North Sea remains unknown. Possible explanations include differences in the density of haul-out groups, variations in previous exposure to morbilliviruses or differences in immune status.

(7) Morbillivirus infections are extant in both North Atlantic and Antarctic pinnipeds and in dolphins and porpoises from the Atlantic and the Mediterranean. The morbillivirus responsible for the diseases in high Arctic sled dogs and Baikal seals in 1987-88 was probably identical to CDV, and clearly different from the PDV responsible for the North Sea seal epizootic in 1988.

(8) PDV was probably transmitted to terrestrial carnivores, causing distemper outbreaks in Danish mink farms in 1989. The epizootiological relation between the disease outbreaks in mink and seals needs to be studied further.

(9) Harp seals are a plausible vector of PDV as their populations showed a high prevalence of antibodies to the virus even before the epizootic in 1988. They are also highly migratory and have recently visited European waters. Harp seals were observed in the vicinity of harbour seal haul-out sites during 1986 to 1988.

Acknowledgements. We thank A. Bergman, M. BlixenkroneMoller, T. C. Harder, J. Harwood, P. Have, S. Kennedy, D. M. Lavigne, B. Liess, N. H. Markussen, N. Nørgaard, C. Örvell $R$. Reeves, M. Stede and V Svansson who carefully commented on an earlier version of the manuscript.

\section{LITERATURE CITED}

Addison, R. F., Smith, T G. (1974). Organochlorine residue levels in Arctic ringed seals: variation with age and sex. Oikos 25: 335-337

Addison, R. F., Zinck, M. E. (1986). PCBs have declined more than DDT-group residues in Arctic ringed seals (Phoca hispida) between 1972 and 1981 Environ. Sci. Technol. 20(3): $253-256$

Appel, M. J. (1987). Canine Distemper Virus. In: Appel, M. J (ed.) Virus infections of carnivores. Elsevier Science Publishers, Amsterdam, p. 133-159

Anderson, S., Livens, F. R., Singleton, D. L. (1990). Radionuclides in grey seals. Mar. Pollut. Bull. 21:343-345

Aulerich, R. J., Ringer, R. K. (1977). Current status of PCB toxicity to mink, and effect on the reproduction. Arch. Environ. Contam. Toxicol. 6: 279-292

Baden, S. P., Loo, L.-O., Pihl, L., Rosenberg, R. (1990). Effects of eutrophication on benthic communties including fish: Swedish West Coast. Ambio 19 (3): 113-122

Baker, J. R. (1992). The pathology of phocine distemper Sci. total Environ. 1.15: in press

Baker, J. R., Ross, H. M. (1992). The role of bacteria in phocine distemper. Sci. total Environ. 115: in press

Barrett, T., Crowther, J., Osterhaus, A. D. M. E., Subbarao, S. M., Groen, J., Haas, L., Mamaev, L. V., Titenko, A. M., Grachev, M. A., Visser, I. K. G., Bostock, C. J. (1992). 
Molecular biological and serological studies on the recent seal virus epizootics in Europe and Siberia. Sci. total Environ. 115: in press

Bengtson, J. L., Boveng, P., Franzén, U., Have, P., HeideJorgensen, M.-P., Härkönen, T (1991). Antibodies to canine distemper virus in Antarctic seals. Marine Mammal Sci. $7: 85-87$

Bergman, A., Olsson, M. (1985). Pathology of Baltic grey seal and ringed seal females, with special reference to adrenocortical hyperplasia: is environmental pollution the cause of a widely distributed disease syndrome? Finnish Game Res. 44: $47-62$

Bergman, A., Olsson, M., Reiland, S. (1986). High frequency of skeletal deformities in skulls of the Baltic grey seal. Comm. Meet. int. Coun. Explor. Sea C.M.-ICES/N:15 1-7

Bergman, A., Järplid, B., Svensson, B. -M. (1990). Pathological findings indicative of distemper in European seals. Vet. Microbiol. 23: 331-341

Bjørge, A. (1987). Parasitic nematodes in stomachs of grey seals, Halichoerus grypus and common seals, Phoca vitulina in Norwegian coastal waters. Conseil International de la Chasse et de la Conservation du Gibier. Report from the International Workshop on Coastal Seals. Oslo, April 28-29: 184-193

Bleavins, M. R., Aulerich, R. J., Ringer, R. K. (1980). Polychlorinated biphenyls (Aroclor 1016 and 1242): effects on survival and reproduction in mink and ferrets. Arch. Environ. Contam. Toxicol 9: 627-635

Blixenkrone-Møller, M., Svansson, V., Have, P., Bøtner, A., Nielsen, A. (1989). Infection studies in mink with sealderived morbillivirus. Arch. Virol. 106: 165-170

Bohm, J., Blixenkrone-Møller, M., Lund., E. (1989). A serious outbreak of canine distemper among sled-dogs in northern Greenland. Arct. Med. Res. 48:195-203

Bostock, C. J., Barrett, T., Crowther, J. R. (1990). Characterisation of the European seal morbillivirus. Vet. Microbiol. 23: $351-360$

Boulva, J., McLaren, I. A. (1979). Biology of the harbor seal, Phoca vitulina, in eastern Canada. Bull. Fish Res. Bd Can. 200: $24 \mathrm{pp}$

Breuer, E. M., Ernst, R. H., Hofmeister, R. J., Hentschke, J., Mölle, G., Ludwig, H. (1988a). First report of caninedistemper-like disease and lesions in harbor seals: pathologic-histologic findings and virus isolation. Angew. Zool. 2: $129-138$

Breuer, E. M., Ernst, R. H., Hofmeister, R. J., Hörchner, F., Hentschke, J., Mölle, G., Ludwig, H. (1988b). Pathologische, parasitologische und virologische Untersuchungsergebnisse zum Seehundsterben in der Nordsee. Angew. Zool. 2: 237-243

Breuer, E. M., Hofmeister, R. J., Ernst, R. H., Hörchner, F. (1988c). Pathologic-anatomic, histologic and parasitologic findings in harbor seals. Angew. Zool. 2: 139-145

Breuer, E. M., Hofmeister, R., Ernst, R., Höchner, F., Höppner, I. (1988d). Untersuchungen zum Seehundsterben im Wattenmeer vor Sylt 1988: Bedeutung des hochgradigen Lungenwurmbefalls mit hypersensitiver Reaktion. J. Vet. Med. B 35: 467-473

Brouwer, A., Reijnders, P. J. H., Koeman, J. H. (1989). Polychlorinated biphenyl (PCB)-contaminated fish induces vitamin $\mathrm{A}$ and thyroid hormone deficiency in the common seal (Phoca vitulina). Aquat. Toxicol. 15: 99-106

Caines, L. A. (1978). Heavy metals residues in grey seals (Halichoerus grypus) from the Farne Islands. Comm. Meet. int. Coun. Explor. Sea C.M.-ICES/E:40:1-13

Carter, S. D., Hughes, D. E., Bell, S. C., Baker, J. R. (1990). Immune responses of the common seal (Phoca vitulina) to canine distemper antigens during an outbreak of phocid distemper viral infection. J. Zool., Lond. 222: 391-398

Carter, S. D., Hughes, D. E., Taylor, V. J., Bell, S. C. (1992). Immune response in common and grey seals during the seal epizootic. Sci. total Environ. 115: in press

Clausen, B. (1978). Diseases and toxochemicals in the common seal in Denmark. Finnish Game Res, 37: 38-39

Claussen, D., Strauss, V. Ising, S., Jäger, M., Schneider, T., Stoye, M. (1991). The helminth fauna from the common seal (Phoca vitulina vitulina, Linné, 1758) of the Wadden Sea in lower Saxony. Part 2: Nematodes. J. Vet. Med. 38: 649-656

Cornwell, H. J. C., Anderson, S. S., Thompson, P. M., Mayer, S. J., Ross, H. M., Pomeroy, P. P., Munro, R. (1992). The serological response of the common seal (Phoca vitulina) and the grey seal (Halichoerus grypus) to phocine distemper virus as measured by a canine distemper virus neutralisation test. Sci. total Environ. 115: in press

Cosby, S. L., McQuaid, S., Duffy, N., Lyons, C., Rima, B. K., Allan, G. M., McCullough, S. J., Kennedy, S., Smyth, J. A., McNeilly, F., Craig, C., Örvell, C. (1988). Characterization of a seal morbillivirus. Nature, Lond. 336: 115-116

Curran, M. D., O'Loan, D., Rima, B. K., Kennedy, S. (1990). Nucleotide sequence analysis of phocine distemper virus reveals its distinctness from canine distemper virus. Vet. Rec. 127: 430-431

DeLellis, R. A. (1989). The endocrine system. In: Cotran, R. S., Kumar, V., Robbins, S. L. (eds.) Robbins pathologic basis of disease. Saunders Co., Philadelphia, p. 1205-1276

DeLong, R. L., Gilmartin, W. G., Simpson, J. G. (1973). Premature births of California sea lions: associated with high organochlorine pollutant residue levels. Science 181: $1168-1169$

Dietz, R., Hansen, C. T., Have, P., Heide-Jørgensen, M.-P. (1989a). Clue to seal epizootic. Nature, Lond. 338: 627

Dietz, R., Heide-Jørgensen, M.-P., Härkönen, T (1989b). Mass deaths of harbor seals (Phoca vitulina) in Europe. Ambio 18(5): 258-264

Dietz, R., Heide-Jørgensen, M.-P., Härkönen, T., Teilmann, J., Valentin, N. (1991). Age determination of European harbour seal, Phoca vitulina L. Sarsia 76: 17-21

Domingo, M., Ferrer, L., Pumarola, M., Marco, A., Plana, J., Kennedy, S., McAliskey, M., Rima, B. K. (1990). Morbillivirus in dolphins. Nature, Lond. 348: 21

Donkin, P., Mann, S. V., Hamilton, E. I. (1981). Polychlorinated biphenyl, DDT and dieldrin residues in the grey seal (Halichoerus grypus) males, females and mother-foetus pairs sampled at the Farne Islands, England during the breeding season. Sci. total Environ. 19: 121-142

Drescher, H. E., Harms, U., Huschenbeth, E. (1977). Organochlorines and heavy metals in harbour seals (Phoca vitulina) from the German North Sea coast. Mar. Biol. 41: 99-106

Duinker, J. C., Hillebrand, M. T. J., Nolting, R. F. (1979). Organochlorines and heavy metals in harbour seals (Dutch Wadden Sea). Mar. Pollut. Bull. 10: 360-364

Duguy, R. (1988). Cetaces et pinnipedes observes sur les côtes francaises en 1987. Comm. Meet. int. Coun. Explor. Sea C.M.-ICES/N:2: $1-4$

Duguy, R. (1989). Rapport annuel sur les cetaces et pinnipedes trouves sur les côtes de France - année 1987. Comm. Meet. int. Coun. Explor. Sea C.M.-ICES/N:4 : 1-4

Edler, L. (1986). Produktion och näringsupptag av alger. In: National Swedish Protection Board. Report 3272 (Rosenberg, ed.): $62-69$

Eis, D. (1989). Simplification in the etiology of recent seal deaths. Ambio 18: 144 
Feldman, E. C. (1983). Hyperadrenocorticism. In: Ettinger, S. J. (ed. ) Textbook of veterinary internal medicine. Diseases of the dog and cat. Saunders Co., Philadelphia, $p$ $1672-1696$

Frey, H.-R., Liess, B., Haas, L., Lehmann, H., Marschall, H. -J (1989). Herpesvirus in harbour seals (Phoca vitulina). J Vet. Med. B 36: 699-708

Geraci, J. R., Fortin, J. F., Aubin, D. J. St., Hicks, B. D. (1981) The seal louse, Echinopthirius horridus: an intermediate host of the seal heartworm, Dipetalonema spirocauda (Nematoda). Can. J. Zool. 59: 1457-1459

Geraci, J R., Aubin, D. J. St., Barker, I. K., Webster, R. G. Hinshaw, V. S., Bean, W. J., Ruhnke, H. L., Prescott, J. H. Early, G., Baker, A. S., Madoff, S., Schooley, R. T. (1982) Mass mortality of harbor seals: Pneumonia associated with influenza A virus. Science 215: 1129-1131

Geraci, J. R., Aubin, D. J. St., Barker, I. K., Hinshaw, V. S., Webster, R. G., Ruhnke, H. L. (1984). Susceptibility of grey (Halichoerus grypus) and harp (Phoca groenlandica) seals to the influenza and mycoplasma of epizootic pneumonia of harbour seals (Phoca vitulina). Can. J. Fish. Aquat. Sci. 41: $151-156$

Geraci, J. R. (1989a). Clinical investigation of the 1987-88 mass mortality of bottlenose dolphins along the U.S. central and south Atlantic coast. Final report to National Marine Fisheries Service and U.S. Navy, Office of Naval Research and Marine Mammal Comission: $63 \mathrm{pp}$.

Geraci, J. R. (1989b). Sea mammals encounter fatal toxins. 8th Biennial Conference on the Biology of Marine Mammals. Marine Mammal Society, Pacific Grove, CA, Abstract

Geraci, J. R., Anderson, D. M., Timperi, R. J., Aubin, D. J. St., Early, G. A., Prescott, J. H., Mayo, C. A. (1989). Humpback whales (Megaptera novaeangliae) fatally poisoned by dinoflagellate toxin. Can. J Fish. Aquat. Sci. 46 (11): $1895-1898$

Gilmartin, W. G., DeLong, R. L., Smith, A. W., Sweeney, J. C., de Lappe, B. W., Riseborough, R. W., Griner, L. A., Dailey, M. D., Peakall, D. B. (1976). Premature parturition in the California sea lion. J. Wildl. Dis. 12: 104-115

Goodhart, C. B. (1988). Did virus transfer from harp seals to common seals. Nature, Lond. 336: 21

Gorham, J. R. (1966). The epizootiology of distemper. J. Adl. Vet. Med. Ass. $149(5): 610-622$

Grachev, M. A., Kumarev, V. P., Mamaev, L. V., Zorin, V. L., Baranova, L. V., Denikina, N. N., Belikov, S. I., Petrov, E. A., Kolesnik, V. S., Kolesnik, R. S., Dorofeev, V. M., Beim, A. M., Kudelin, V. N., Nagieva, F. G., Sidorov, V. N. (1989). Distemper virus in Baikal seals. Nature, Lond. 338: 209

Grenfell, B. T., Lonergan, M. E., Harwood, J. (1992). Quantitative investigations of the epidemiology of phocine distemper virus (PDV) in European common seal populations. Sci. total Environ. 115: in press

Haas, L., Barrett, T., Harder, T., Bostock, C. J. (1990). Detection of Phocine Distemper Virus using the Polymerase Chain Reaction. Dtsch. Tierärztl. Wochenschr. 97 (2): 93-95

Haas, L., Subbarao, S. M., Harder, T., Liess, B., Barrett, I. (1991). Detection of phocid distemper virus RNA in seal tissues using slot hybridisation and the polymerase chain reaction amplification assay: genetic evidence that the virus is distinct from canine distemper virus. J. gen. Virol. 72: $825-832$

Hall, A. J., Pomeroy, P. P., Harwood, J. (1992a). The descriptive epizootiology of phocine distemper in the UK during 1988/89. Sci. total Environ. 115: in press

Hall, A. J., Law, R. J., Wells, D. E., Harwood, J., Ross, H. M., Kennedy, S., Allchin, C. R., Campbell, L. A., Pomeroy, P. P. (1992b). Organochlorine levels in common seals (Phoca vitulina) which were victims and survivors of the 1988 phocine distemper epizootic. Sci. total Environ. 115: in press

Harder, T., Willhaus, T., Frey, H. -R., Liess, B. (1990). Morbillivirus infections of seals during the 1988 epidemic in the Bay of Helgoland. J. Vet. Med. B 37: 641-650

Harder, T C., Moenning, V., Greiser-Wilke, I., Barrett, T. Liess, B. (1991). Analysis of antigenic differences between sixteen phocine distemper virus isolates and other morbilliviruses. Arch. Virol. 118: 261-268

Härkönen, T., Heide-Jørgensen, M.-P. (1990a). Comparative life histories of East Atlantic and other harbour seal populations. Ophelia 32 (3): 211-235

Härkönen, T., Heide-Jørgensen, M.-P. (1990b). Short-term effects of the mass dying of harbour seals in the KattegatSkagerrak area during 1988. Z. Säugetierkde 55: 233-238

Harms, U., Drescher, H. E., Huschenbeth, E. (1978). Further data on heavy metals and organochlorines in marine mammals from German coastal waters. Meeresforsch. 26 : $153-161$

Harwood, J., Carter, S. D., Hughes, D. E., Bell, C. E., Baker, J. R., Cornwell, H. J. C. (1989). Seal disease predictions. Nature, Lond. 339: 670

Harwood, J., Hall, A. (1990). Mass mortality in marine mammals: its implications for population dynamics and genetics. TREE 5, August: 254-257

Harwood, J, Grenfell, B. (1990). Long term risks of recurrent seal plagues. Mar. Pollut. Bull. 21: 284-287

Harwood, J., Hiby, L., Thompson, D., Ward, A. (1991). Seal stocks in Great Britain. Surveys conducted between 1986 and 1989. NERC news January 1991: 11-15 and corrections in July 1991: 35

Have, P., Nielsen, J., Bottner, A. (1992). The seal death in Danish waters. 2. Virological studies. Acta vet. Scand. (in press)

Heide-Jorgensen, M.-P., Härkönen, T (1988). Rebuilding seal stocks in the Kattegat-Skagerrak. Marine Mammal Sci. 4 (3): $231-246$

Heide-Jørgensen, M.-P., Härkönen, T (1992). Epizootiology of the seal disease in the eastern North Sea. J. appl. Ecol. 29: in press

Heidemann, G. (1987). Development and present situation of common seal in Schleswig-Holstein. Conseil International de la Chasse et de la Conservation du Gibier. Report from the international workshop on coastal seals. April 28-29: $39-47$

Heje, N.-I., Henriksen, P. Aalbæk, B. (1992). The seal death in Danish waters 1.988: 1. Acta. vet. Scand. (in press)

Helle, E., Olsson, M., Jensen, S. (1976a). DDT and PCB levels and reproduction in ringed seal from the Bothnian Bay. Ambio 5: 188-189

Helle, E., Olsson, M. Jensen, S. (1976b). PCB levels correlated with pathological changes in seal uteri. Ambio 5: $261-263$

Helle, E., Hyvärinen, H., Stenman, O. (1985). PCB and DDT levels in the Baltic and Saimaa seal population. Finnish Game Res. 44: 63-68

Henderson, G., Trudgett, A., Lyons, C., Ronald, K. (1992). Demonstration of antibodies in archival sera from Canadian seals reactive with a European isolate of Phocine Distemper Virus. Sci. total Environ. 115: in press

Henrikson, K., Karppanen, E., Helminen, M. (1969). Kvicksilverhalter hos insjö- och havssälar. Nordisk Hygienisk Tidskrift: $54-59$

Heppleston, P. B., French, M. C. (1973). Mercury and other metals in British seals. Nature, Lond. 243: 302-304 
Hofmeister, R., Breuer, E., Ernst, R., Hentschke, J., Mölle, G., Ludwig, H. (1988). Distemper-like disease in harbor seals: virus isolation, further pathologic and serologic findings. J. Vet. Med. B 35: 765-769

Holden, A. V. (1972). Monitoring organochlorine contamination of the marine environment by the analysis of residues in seals. In: Ruivo, M. (ed.) Marine pollution and sea life. Fishing News Book, London, p. 266-272

Holden, A. V. (1978). Organochlorine residues in blubber of grey seals (Halichoerus grypus) from the Farne Islands. Comm. Meet. int. Coun. Explor. Sea C.M.-ICES/E:41: 1-6

Horvat, B., Willhaus, T., Frey, H. R., Liess, B. (1989). Herpesvirus in harbour seals (Phoca vitulina): transmission in homologous host. J. Vet. Med. B 36: 715-718

Howes, C. A. (1989). Recent occurrences of harp seal, Phagophilus groenlandicus (Erxleben), in the North Sea. Naturalist 114: 17-19

ICES (1989). Report of the joint meeting of the working group on Baltic seals and the study group on the effects of contaminants on marine mammals. Helsinki, Finland, 15-18 May 1989. C. M. 1989/N:9 (Available from International Council for the Exploration of the Sea, Palæegade 2-4, DK-1261 Copenhagen $\mathrm{K}$, Denmark)

ICES (1990). Report of the joint meeting of the working group on Baltic seals and the study group on the effects of contaminants on marine mammals. Stockholm, 14-17 May 1990. CM 1990/N:14 (Available from International Council for the Exploration of the Sea, Palægade 2-4, DK-1261 Copenhagen K, Denmark)

Jäger, M., Liess, B., Harder, T., Ising, S., Stoye, M. (1990). Experimental inoculation of Beagle dogs permits serological differentiation of phocine and canine distemper virus Wien. Tierärztl. Monatschr. 77 (4): 105-108

Jensen, S., Kihlström, J. E., Olsson, M., Lunberg, C., Örberg, J. (1977). Effects of PCB and DDT on mink (Mustela vison) during the reproductive season. Ambio 6: 239

Kendall, M. D., Safieh, B., Harwood, J., Pomeroy, P. P. (1992) Plasma thymulin concentrations, the thymus and organochlorine contaminant levels in seals infected with phocine distemper virus. Sci total Environ. 115: in press

Kennedy, S. (1990). A review of the 1988 European seal morbillivirus epizootic. Vet. Rec. 127: 563-567

Kennedy, S., Smyth, J. A., McCullough, S. J., Allen, G. M., MCNeilly, F. MCQuaid, S. (1988a). Confirmation of cause of recent seal deaths. Nature, Lond. 335: 404

Kennedy, S., Smyth, J. A., Cush, P. F., Mccullough, S. J., Allan, G. M., McQuaid, S. (1988b). Viral distemper now found in porpoises. Nature, Lond. 336: 21

Kennedy, S., Smyth, J. A., Cush, P. F., McCullough, S. J., Allan, G. M., McQuaid, S. (1989a). Transatlantic spread of seal virus. Nature, Lond. 337: 695

Kennedy, S., Smyth, J. A., Cush, P. F., Duignan, P., Platten, M., McCullough, S. J., Allan, G. M. (1989b). Histopathologic and immunocytochemical studies of distemper in seals. Vet. Pathol. 26: 97-103

Kennedy, S., Smyth, J. A., Cush, P. F., McAliskey, M., McCullough, S. J., Rima, B. K. (1991). Histopathologic and immunocytochemical studies of distemper in harbor porpoises. Vet. Pathol. 28: 1-7

Kirchhoff, H., Binder, A., Liess, B., Friedhoff, K. T., Pohlenz, J, Stede, M., Willhaus, $T$ (1989). Isolation of mycoplasmas from diseased seals. Vet. Rec. 13: 513-514

Klingeborn, B. (1990). Rapport från projektet valpsjukeliknande virus hos säl före och efter sälepizootin orsakad av ett saddant virus 1988. 5 pp Available from the Swedish Environmental Protection Board, S-171 85 Solna, Sweden
Klinowska, M. (1989). Transatlantic spread of seal virus Nature, Lond. 337: 695

Kreiber, M., Barrette, C. (1984). Aggregation behaviour of harbour seals at Forillon National Park, Canada. J. Anim. Ecol. 53: 913-928

Krogsrud, J., Evensen, Ø., Holt, G., Høie, S., Markussen, N. H (1990). Seal distemper in Norway in 1988 and 1989. Vet. Rec. 5: 460-461

Larsen, B. H., Clausen, B., Jensen, B., Tougaard, S. (1987). Gronlandssæler (Phoca groenlandica) i Danmark foråret 1987. Flora og fauna 93(3): 77-79

Lavigne, D. M., Schmitz, O. J. (1990). Global warming and increasing population densities: a prescription for seal plagues. Mar. Pollut. Bull. 21: 280-284

Law, R. J., Allchin, C. R., Harwood, J. (1989a). Concentrations of organochlorine compounds in the blubber of seals from eastern and north-eastern England, 1988. Mar. Pollut. Bull. 20 (3): 110-115

Law, R. J., Allchin, C. R., Harwood, J. (1989b). Reply. Mar Pollut. Bull. 20 (11): 583-584

Law, R. J., Fileman, C. F., Hopkins, A. D., Baker, J. R., Harwood, J., Jackson, D. B., Kennedy, S., Martin, A. R. Morris, R. J. (1991). Concentrations of trace metals in the livers of marine mammals (seals, porpoises and dolphins) from waters around the British Isles. Mar. Pollut. Bull 22(4): 183-191

Laws, D., Taylor, R. J. F. (1957). A mass dying of crabeater seals, Lobodon carcinophagus (Gray). Proc. Zool. Soc. Lond. 129: 315-324

Leighton, T., Ferguson, M., Gunn, A., Henderson, E., Stenhouse, G. (1988). Canine distemper in sled dogs. Can. Vet J. 29: 299

Lick, R. R. (1989). Stomach nematodes of harbour seal Phoca vitulina from the German and Danish Wadden Sea. Comm. Meet. int. Coun. Explor. Sea C.M.-ICES/N:7 $1-22$

Liess, B., Frey, H. -R., Zaghawa, A. (1989a). Morbilliviruses in seals: Isolation and some growth characteristics in cell cultures. Dtsch. Tierärztl. Wochenschr. 96: 180-182

Liess, B., Frey, H. R., Zaghawa, A., Stede,M. (1989b). Morbillivirus infection of seals (Phoca vitulina) during the 1988 epidemic in the Bay of Helgoland. J. Vet. Med. B 36: $601-608$

Liess, B., Frey, H. R., Willhaus, T., Zaghawa, A. (1989c). Morbillivirus infection among seals (Phoca vitulina) during the 1988 epidemic in the Bay of Helgoland. J. Vet. Med. B 36: 709-714

Likhoshway, Y V., Grachev, M. A., Kumarev, V. P., Solodin, Y V., Goldberg, O. A., Belykh, O. I., Nagieva, F. G., Nikulina, V. G., Kolesnik, B. S. (1989). Baikal seal virus. Nature, Lond. 339: 266

Lindstedt, 1. (1990). Vad berattar fynden av tumlare? Fauna och flora 85: $122-128$

Lunneryd, S. G. (1991). Anisakid nematodes in the harbour seal Phoca vitulina from the Kattegat-Skagerrak and the Baltic. Ophelia 34(2): 105-115

Lunneryd, S. G. (1992). Dipetalonema spirocauda (Leidy) (Nematoda) and Corynosoma strumosum (Rudolphi) (Acanthocephala) infection in harbour seals from the Kattegat-Skagerrak and the Baltic. Sarsia 76: 267-271

Machida, M. (1971). Survey of gastric nematodes in the stomach of northern fur seals caught in the western Pacific, of the coast of northern Japan. Jap. J. Parasitol. 20 371-378 (In Japanese)

Mahy, B. W. J., Barrett, T., Evans, S., Anderson, E. C., Bostock, C. J. (1988). Characterization of a seal morbillivirus. Nature, Lond. 336: 115 
Markussen, N. H. (in press). Apparent decline in the harbour seal (Phoca vitulina) population near Hvaler, Norway, following an epizootic. Holarct. Ecol.

Markussen, N. H., Have, P. (1992). Phocine distemper virus infection in harp seals (Phoca groenlandica). Mar. Mammal Sci. 8: 19-26

Marsh, S.-L., Scheibel, W. (1989). Untersuchungen zum Altersaufbau eines Seehundbestands. Analysen an Totgefundenen aus Schleswig-Holstein. - Institut für Haustierkunde der Christian-Albrechts-Universität, Kiel. Zoologische und Ethologische Untersuchungen zum Robbensterben

Martin, J. H., Elliot, P. D., Anderlini, V. C., Girvin, D., Jacobs, S. A., Risebrough, R. W., DeLong, R. L., Gilmartin, W. G. (1976). Mercury-selenium-bromine imbalance in premature parturient California sea lions. Mar. Biol. 35: 91-104

Martin, A. R., Reynolds, P., Richardson, M. G. (1987). Aspects of the biology of Pilot whales (Globicephala melaena) in recent mass strandings on the British coast. J. Zool., Lond. 211. 11-23

McClelland, G. (1980). Phocanema decipiens: pathology in seals. Expl Parasit. 49: 405-419

McCullough, S. J., McNeilly, F., Allan, G. M., Kennedy, S., Smyth, J. A.. Cosby, S. L., McQuaid, S., Rima, B. K. (1991). Isolation and characterisation of a porpoise morbillivirus. Arch. Virol. 118: 247-252

McGourty, C. (1988). Species jump may be responsible for seals' virus infection. Nature, Lond. 335: 3

Miller, J. A. (1989). Diseases for our future. Bioscience 39 (8): 509-517

Mitchell, E., Reeves, R. (1981). Catch history and cumulative catch estimates of initial population size of cetaceans in the Eastern Canadian Arctic. Rep. int. Whal. Commn 31 $645-682$

Mitchell, S. H., Kennedy, S. (1992). Tissue concentrations of organochlorine compounds in common seals from the coast of Northern Ireland. Sci. total Environ. 115: in press

Mortensen, P., Bergman, A., Bignert, A., Hansen, H. J., Härkönen, T., Olsson, M. (1991). Utbredning och förekomst av käkskador hos knubbsäl, Phoca vitulina, i svenska och danska museisamlingar från perioden 1835-1988. 14 pp. (Available from the Swedish Environmental Protection Board, S-17185 Solna)

Munro, R., Ross, H. M., Cornwell, H. J. C., Gilmour, J. (1992) Disease conditions affecting common seals (Phoca vit ulina) around the Scottish mainland, September-November 1988. Sci. total Environ. 115 in press

Muir, D. C. G., Norstrom, R. J., Simon, M. (1988). Organochlorine contaminants in Arctic marine food chains: accumulation of specific polychlorinated biphenyls and chlordane related compounds. Environ. Sci. Technol. 22(9) $1071-1079$

Muir, D. C. G., Ford, C. A., Stewart, R. E. A., Smith, T G. Addison, R. F., Zinck, M. E., Béland, P. (1990). Organochlorine contaminants in beluga (Delphinapterus leucas) from Canadian waters. In: Smith, T G., Geraci, J., St. Aubin, D. J. (eds.) Can. Bull. Fish. Aquat. Scl. 224 $165-190$

Nunoya, T., Tajima, M., Ishikawa, Y., Samejima, T., Ishikawa H., Hasegawa, K. (1990). Occurrence of a canine distemper-like disease in Aquarium seals. Jap. J. Vet. Sci 52(3): $469-47$ ?

Oehme, M., Fürst, P., Kruger, M., Meemken, H. A., Groebel W. (1988). Presence of polychlorinated dibenzo-p-dioxins dibenzofurans and pesticides in the Arctic seal from Spitsbergen. Chemosphere 17: 1291-1300

Ofstad, E. B., Martinsen, K (1983). Persistent organochlorine compounds in seals from Norwegian coastal waters. Ambio 12: 262-264

Olsson, M., Johnels, A. G., Vaz, R. (1975). DDT and PCB levels in seals from Swedish waters. The occurrence of aborted seal pups. In: Proceedings from the Symposium on the seal in the Baltic, Lidingö. Sweden, June 4-6, 1974 Report from the National Swedish Environmental Protection Agency PM 591. 43-65

Olsson, M., Reutergårdh, L. (1986). DDT and PCB pollution trends in the Swedish aquatic environment. Ambio 15(2): $103-109$

Örberg, J., Johansen, N., Kihlström, J. E., Lundberg, C. (1972). Administration of DDT and PCB prolongs oestrous cycle in mice. Ambio 1(4): 148-149

Örberg, J., Kihlström, J. E. (1973). Effect of long-term feeding of polychlorinated biphenyls ( $\mathrm{PCB}$, Clorphen A 60) on the length of the oestrous cycle and the frequency of implantated ova in the mouse. Environ. Res. 6: 176-179

Örberg, J., Lundberg, C. (1974). Some effects of DDT and $\mathrm{PCB}$ on the hormonal system in the male mouse. Environ. Physiol. Biochem. 4: 116-120

Örvell, C., Blixenkrone-Møller, M., Svansson, V., Have, P. (1990). Immunological relationships between phocid and canine distemper virus studied with monoclonal antibodies. J. gen. Virol. 71: 2085-2092

Osterhaus, A. D. M. E. (1988). Seal death. Nature, Lond. 334 301-302

Osterhaus, A. D. M. E., Vedder, E. J (1988). Identification of virus causing recent seal deaths. Nature, Lond. 335: 20

Osterhaus, A. D. M. E., Yang, H., Spijkers, H. E. M., Groen, J., Teppema, J. S., Van Steenis, G. (1985). The isolation and partial characterization of a highly pathogenic herpesvirus from the harbor seal (Phoca vitulina). Arch. Virol. 86 $239-251$

Osterhaus, A. D. M. E., Vedder, L., Zarnke, R., Spijkers, I (1987). Prevalence of virusneutralizing antibodies to seal herpesvirus (Phocid herpesvirus 1) in different pinniped species. 7th Biennial Conference on the Biology of Marine Mammals. Marine Mammal Society, Miami, Florida, Abstract

Osterhaus, A. D. M. E., Groen, J., Vries, P. De, UytdeHaag, F. G. C. M., Klingeborn, B., Zarnke, R. (1988). Canine Distemper Virus in seals. Nature, Lond. 335: 403-404

Osterhaus, A. D. M. E., UytdeHaag, F. G. C. M., Visser, I. K. G., Vedder, E. J., Reijnders, P. J. H., Kuiper, J., Brugge, H N. (1989a). Seal vaccination success. Nature, Lond. 337 21

Osterhaus, A. D. M. E., Groen, J., UytdeHaag, F G. C. M., Visser, I. K. G., Bildt, M. W. G. v. d., Bergman, A., Klingeborn, B. (1989b). Distemper virus in Baikal seals. Nature, Lond. 338: 209-210

Osterhaus, A. D. M. E., Broeders, H. W. J., Groen, J., UytdeHaag, F G. C. M., Visser, I. K. G., Bildt, M. W. G. v. d. Örvell, C., Kumarev, V. P., Zorin, V. L. (1989c). Different morbilliviruses in European and Siberian seals. Vet. Rec. 23/30: $647-648$

Osterhaus, A. D. M. E., Groen, J., UytdeHaag, F. G. C. M., Visser, I. K. G., Vedder, E. J., Crowther, J., Bostock, C. J. (1989d). Morbillivirus infections in European seals before 1988. Vet. Rec. 16: 326

Osterhaus, A. D. M. E., Groen, J., Spijkers, H. E. M., Broeders, H. W. J., UytdeHaag, F. G. C. M., Vries de P., Teppema, J. S., Visser, I. K. G., Bildt v. d. M. W. G., Vedder, E. J. (1990). Mass mortality in seals caused by a newly discovered morbillivirus. Vet. Microbiol. 23: 343-350

Peakall, D. B. (1967). Pesticide-induced enzyme breakdown of steroids in birds. Nature, Lond 216: 505-506 
Perrin, W. F. (1988). Mass die-offs are a factor in survival of populations. International Union for the Conservation of Nature and Natural Resources, Newsletter of the cetacean specialist group 4: 10

Perttilä, M. Stenman, O., Pyysalo, H., Wickström, K. (1986). Heavy metals and organochlorine compounds in seals in the Gulf of Finland. Mar. environ. Res. 18: 43-59

Platonow, N. S., Karstad, L. H. (1973). Dietary effects of polychlorinated biphenyls on mink. Can. J. Comp. Med. $37(4)$ : $391-400$

Pohlmeyer, G. (1990). Morphologische Untersuchungen der Darmschleimhaut und des Darmschleimhautimmunsystems bei Seehunden (Phoca vitulina vitulina L.) im Verlauf des Seuchenzuges 1988. Summary of dissertation, Hannover Veterinary School: 138-139

Reijnders, P. J. H. (1980). Organochlorine and heavy metal residues in harbour seals from the Wadden Sea and their possible effects on reproduction. Neth. J. Sea Res. 14: $30-65$

Reijnders, P. J. H. (1986). Reproductive failure in common seals feeding on fish from polluted coastal waters. Nature, Lond. 324: 456-457

Reijnders, P. J. H. (ed.) (1989). International workshop seal disease epidemic. Research Institute for Nature Management, AB Den Burg, The Netherlands, 27 pp.

Reijnders, P. J. H. (1990). Present and future threats of pollution to pinnipeds. International Union for the Conserva tion of Nature and Natural Resources, Seal Specialist Group: 98-104

Rima, B. K., Cosby, S. L., Duffy, N., Lyons, C., O'Loan, D., Kennedy, S., McCullough, S. J., Smyth, J. A., McNeilly, F (1990). Humoral responses in seals infected by phocine distemper virus. Res. Vet. Sci. 49: 114-116

Rima, B. K., Curran, M. D., Kennedy, S. (1992). Phocine distemper virus, the agent responsible for the 1988 mass mortality of seals. Sci. total Environ. 115: in press

Roberts, T. M., Heppleston, P. B., Roberts, R. D. (1976). Distribution of heavy metals in tissues of the common seal. Mar Pollut. Bull. 7 (10): $194-196$

Rosenberg, R., Lindahl, O., Blanck, H. (1988). Silent spring in the sea. Ambio 17: 289-290

Safe, S. (1984). Polychlorinated biphenyls (PCBs) and polybrominated biphenyls (PBBs): biochemistry, toxicology, and mechanism of action. CRC Crit. Rev. Toxicol. 13: 319-395

Schumacher, U., Horny, H.-P., Heidemann, G., Schultz, W. Welsch, U. (1990). Histopathological findings in harbour seals (Phoca vitulina) found dead on the German North Sea coast. J. comp. Path. 102: 299-309

Schneider, D. C., Payne, P. M. (1983). Factors affecting haulout of harbor seals at a site in southeastern Massachusetts. J. Mammal. 64: 518-520

Scott, D. W. (1979). Hyperadrenocorticism (hyperadrenocorticoism, hyperadrenocorticalism, Cushings' disease, Cushings' syndrome). Vet. Clin. N. Amer. 9 (1): 3-28

Simmonds, M. P., Johnston, P. A. (1989). Seals, sense and science. Mar. Pollut. Bull. 20: 580-583

Skaare, J. U., Markussen, N. H., Norheim, G., Haugen, S., Holt, G. (1990). Levels of polychlorinated biphenyls, organochlorine pesticides, mercury, cadmium, copper, selenium, arsenic, and zinc in the harbour seal, Phoca vitulina, in Norwegian waters. Environ. Pollut. 66: 309-324

Smith, J. W. (1989). Ulcers associated with larval Anisakis simplex B (Nematoda: Ascaridoidea) in the forestomach of harbour porpoises Phocoena phocoena (L.). Can. J. Zool. 67: $2270-2276$
Smith, J. W., Wootten, R. (1978). Anisakis and anisakiasis. Adv. Parasit. 16: 93-163

Sommers, A. C. (1977). Adrenal glands. In: Anderson, W. A. D., Kissane, J M. (eds.) Pathology. The C. V. Mosby Co. Saint Louis, p. 1658-1679

Stadtländer, C., Hartmann, D., Binder, A, Kirchhoff, $H$. (1989). Investigation of seal mycoplasmas for their cytotoxic potential on tracheal organ cultures of SPF and gnotobiotic rats. Zbl. Bakt. 272: 216-224

Stede, M. (1987). Development and present situation of common seal in Niedersachsen. Conseil International de la Chasse et de la Conservation du Gibier. Report from the international workshop on coastal seals. April 28-29: $48-55$

Stede, M. (1989). Epidemilogy of the seal disease epidemic along the coast of Lower Saxony, FRG. International workshop on current research in seal diseases. Hannover Veterinary School, February 21-22, 1989, Abstract

Stede, M. (1990a). Die Seehundsepidemic ('Seehundsterben') 1988 vor der niedersächsischen Küste. Seehunde und Meeressäuger 8: 25-33

Stede, M. (1990b). Pathologisch-anatomische Untersuchungen an Hundsrobben von der niedersächsischen Küste aus dem Jahr 1989. Seehunde und Meeressäuger 8: 34-47

Stede, G., Stede, M. (1990). Orientierende Untersuchungen von Seehundschädeln auf pathologische Knochenveränderungen. Institut für Haustierkunde der Universität Kiel, Forschungsstelle Wildbiologie, Zwischenbericht zum Vorhaben BMU-Nr, 10805017/06: 31-53

Stenman, O., Tissari, A. (1990). Organochlorines in Baltic seals in the 1980 's. Comm. Meet. int. Coun. Explor Sea C.M.-ICES/N: $12: 1-8$

Stephenson, R. O., Ritter, D. G., Nielsen, C. A. (1982). Serologic survey for canine distemper and infectious canine hepatitis in wolves in Alaska. J. Wildl. Dis. 18: 419-424

Strauss, V., Claussen, D., Jäger, M., Ising, S., Schneider, T., Stoye, M. (1991). The helminth fauna from the common seal (Phoca vitulina vitulina, Linné, 1758) of the Wadden Sea in lower Saxony. Part 1: Trematodes, cestodes and acanthocephala. J. Vet. Med. 38: 641-648

Svansson, V., Arnason, A., Blixenkrone-Moller, M. (1991). Sero-epidemiological studies of morbillivirus infections in whales. International Whaling Commission SC/F91/F22: $1-5$

Tanabe, S. (1988). PCB problems in the future: foresight from current knowledge. Environ. Pollut. 50: 5-28

Tewes, S. (1989). Bacteriological examination of seals. International workshop on current research in seal diseases. Hannover Veterinary School, February 21-22 1989, Abstract

Thompson, P. M., Fedak, M. A., McConnell, B. J., Nicholas, K. $S$. (1989). Seasonal and sex-related variation in the activity patterns of common seals (Phoca vitulina). J. appl. Ecol. 26: $521-535$

Thompson, P. M., Harwood, J. (1990). Methods for estimating the population size of common seals, Phoca vitulina. J. appl. Ecol. 27: $924-938$

Thompson, P. M., Miller, D. (1992). Phocine distemper outbreak in the Moray Firth common seal population: an estimate of mortality. Sci. total Environ. 115: in press

Thompson, P. M., Cornwell, H. J. C., Ross, H. M., Miller, D. (1992). A serological study of the prevalence of phocine distemper virus in a population of harbour seals in the Moray Firth, N.E. Scotland. J. Wildl. Dis. 28: 21-27

Tougaard, S. (1989). Monitoring harbour seal (Phoca vitulina) in the Danish Wadden Sea. Helgoländer Meeresunters. 43: $347-356$ 
Wassermann, M., Wassermann, D., Cucoc, S., Miller, H. J. (1979). World PCBs map: storage and effect in man and his biologic environment in the 1970s. In: Nicholson, W. J., Moore, J. A. (eds.) Health effects of halogenated aromatic hydrocarbons. Ann. N. Y Acad. Sci. 320: $69-124$

West, G. (ed.) (1979). Black's veterinary dictionary. Adam \& Charles Black, London

Wiig, Ø. (1988). Gronlandssel og selinvasjon. Naturen 2: $35-41$

Visser, I. K. G., Bildt, M. W. G. v. d., Brugge, H. N., Reijnders, P. J. H., Vedder, E. J., Kuiper, J., Vries, P. de, Groen, J., Walvoort, H. C., UytdeHaag, F, G. C. M. Osterhaus, A. D. M. E. (1989). Vaccination of harbour seals (Phoca vitulina) against phocid distemper with two different inactivated

Responsible Subject Editor: M. D. Dailey, Long Beach, California, USA canine distemper virus (CDV) vaccines. Vaccine 7 : $521-526$

Visser, I. K. G., Kumarev, V. P., Örvell, C., Vries, P. de, Broeders, H. W. J., Bildt, M. W. G. v. d., Groen, J., Teppema, J. S., Burger, M. C., UytdeHaag, F. G. C. M., Osterhaus, A. D. M. E. (1990). Comparison of two morbilliviruses isolated from seals during outbreaks of distemper in North West Europe and Siberia. Arch. Virol. 111: $149-164$

Young, P. C. (1972). The relationships between the presence of larval anisakine nematodes in cod and marine mammals. J. appl. Ecol. 9: 459-485

Zakharov, V. M., Yablokov, A. V. (1990). Skull asymmetry in the Baltic grey seal: effects of environmental pollution. Ambio 19 (5): $266-269$

Manuscript first received: February 25, 1991

Revised version accepted: January 29, 1992 